\title{
LEVEL II SCOUR ANALYSIS FOR BRIDGE 8 (WELLTH00020008) on TOWN HIGHWAY 2, crossing WELLS BROOK, WELLS, VERMONT
}

Open-File Report 97-770

Prepared in cooperation with

VERMONT AGENCY OF TRANSPORTATION

and

FEDERAL HIGHWAY ADMINISTRATION

U.S. Department of the Interior

U.S. Geological Survey

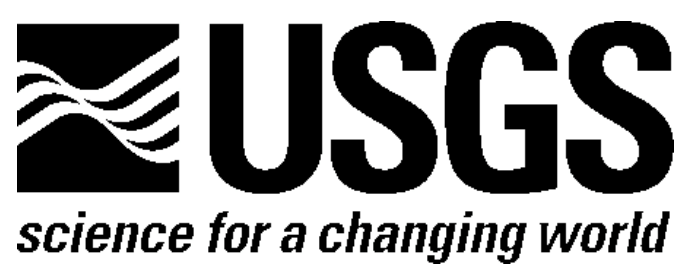




\section{LEVEL II SCOUR ANALYSIS FOR BRIDGE 8 (WELLTH00020008) on TOWN HIGHWAY 2, crossing WELLS BROOK, WELLS, VERMONT}

By LORA K. STRIKER AND MICHAEL A. IVANOFF

U.S. Geological Survey Open-File Report 97-770

Prepared in cooperation with

VERMONT AGENCY OF TRANSPORTATION

and

FEDERAL HIGHWAY ADMINISTRATION 


\title{
U.S. DEPARTMENT OF THE INTERIOR BRUCE BABBITT, Secretary
}

\author{
U.S. GEOLOGICAL SURVEY \\ Mark Schaefer, Acting Director
}

For additional information write to:

District Chief

U.S. Geological Survey 361 Commerce Way

Pembroke, NH 03275-3718
Copies of this report may be purchased from:

U.S. Geological Survey

Branch of Information Services

Open-File Reports Unit

Box 25286

Denver, CO 80225-0286 


\section{CONTENTS}

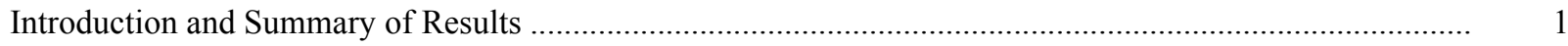

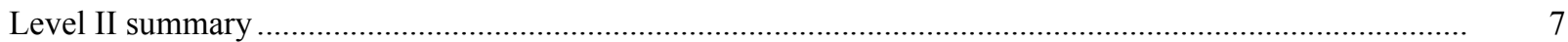

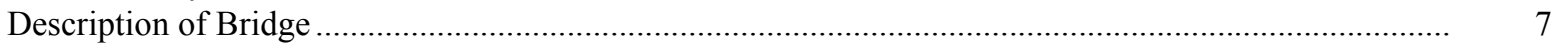

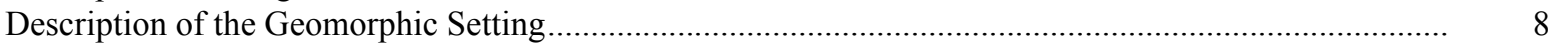

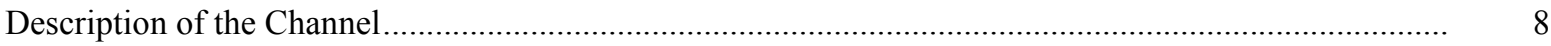

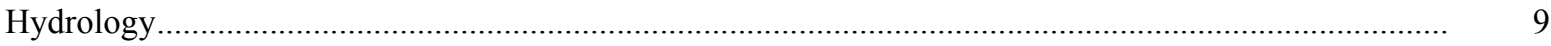

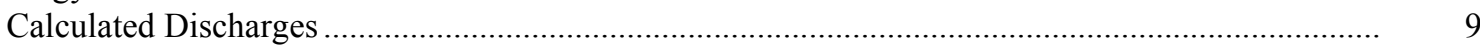

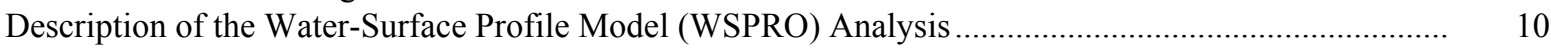

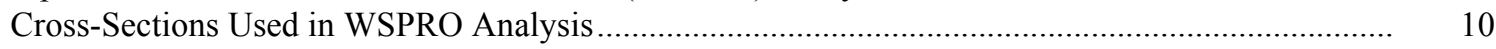

Data and Assumptions Used in WSPRO Model ...................................................................... 11

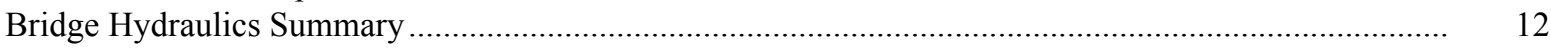

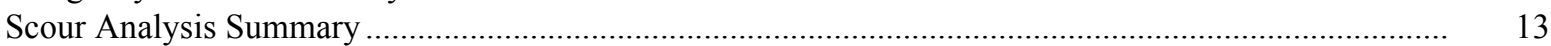

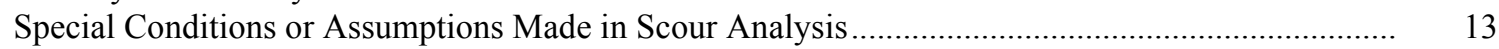

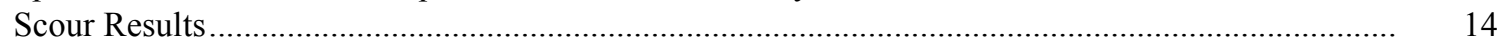

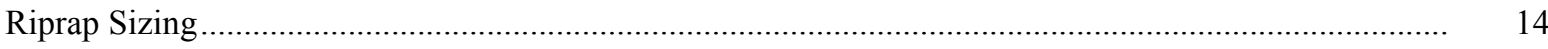

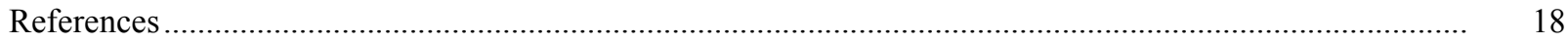

Appendixes:

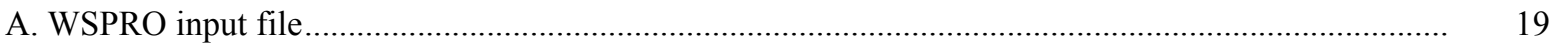

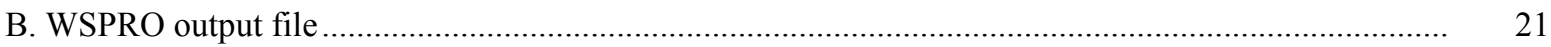

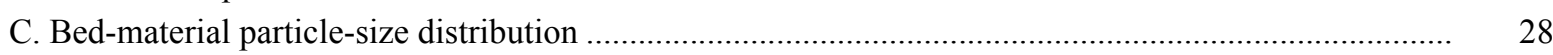

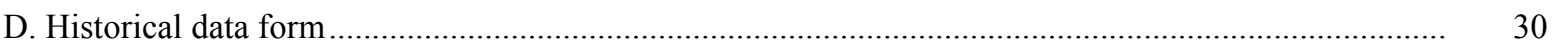

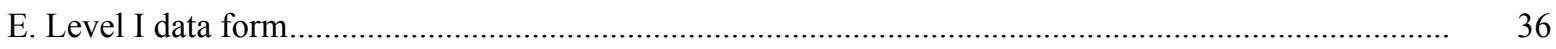

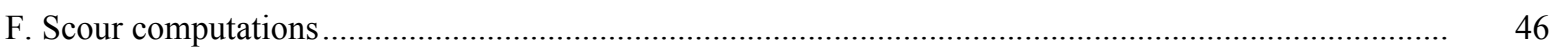

\section{FIGURES}

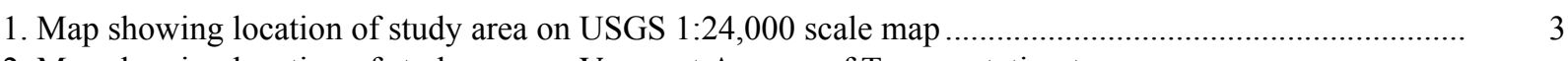

2. Map showing location of study area on Vermont Agency of Transportation town

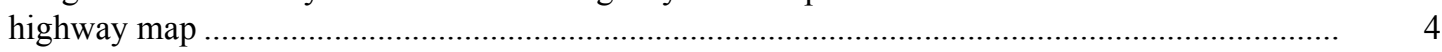

3. Structure WELLTH00020008 viewed from upstream (September 19, 1995) ....................................... 5

4. Downstream channel viewed from structure WELLTH00020008 (September 19, 1995) ...................... 5

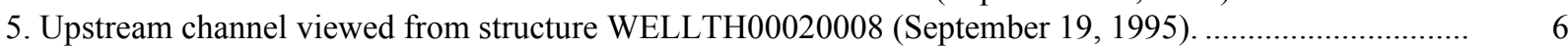

6. Structure WELLTH00020008 viewed from downstream (September 19, 1995).................................. 6

7. Water-surface profiles for the 100- and 500-year discharges at structure

WELLTH00020008 on Town Highway 2, crossing Wells Brook,

Wells, Vermont.

8. Scour elevations for the 100- and 500-year discharges at structure

WELLTH00020008 on Town Highway 2, crossing Wells Brook,

Wells, Vermont.

\section{TABLES}

1. Remaining footing/pile depth at abutments for the 100-year discharge at structure

WELLTH00020008 on Town Highway 2, crossing Wells Brook,

Wells, Vermont

2. Remaining footing/pile depth at abutments for the 500-year discharge at structure

WELLTH00020008 on Town Highway 2, crossing Wells Brook,

Wells, Vermont 


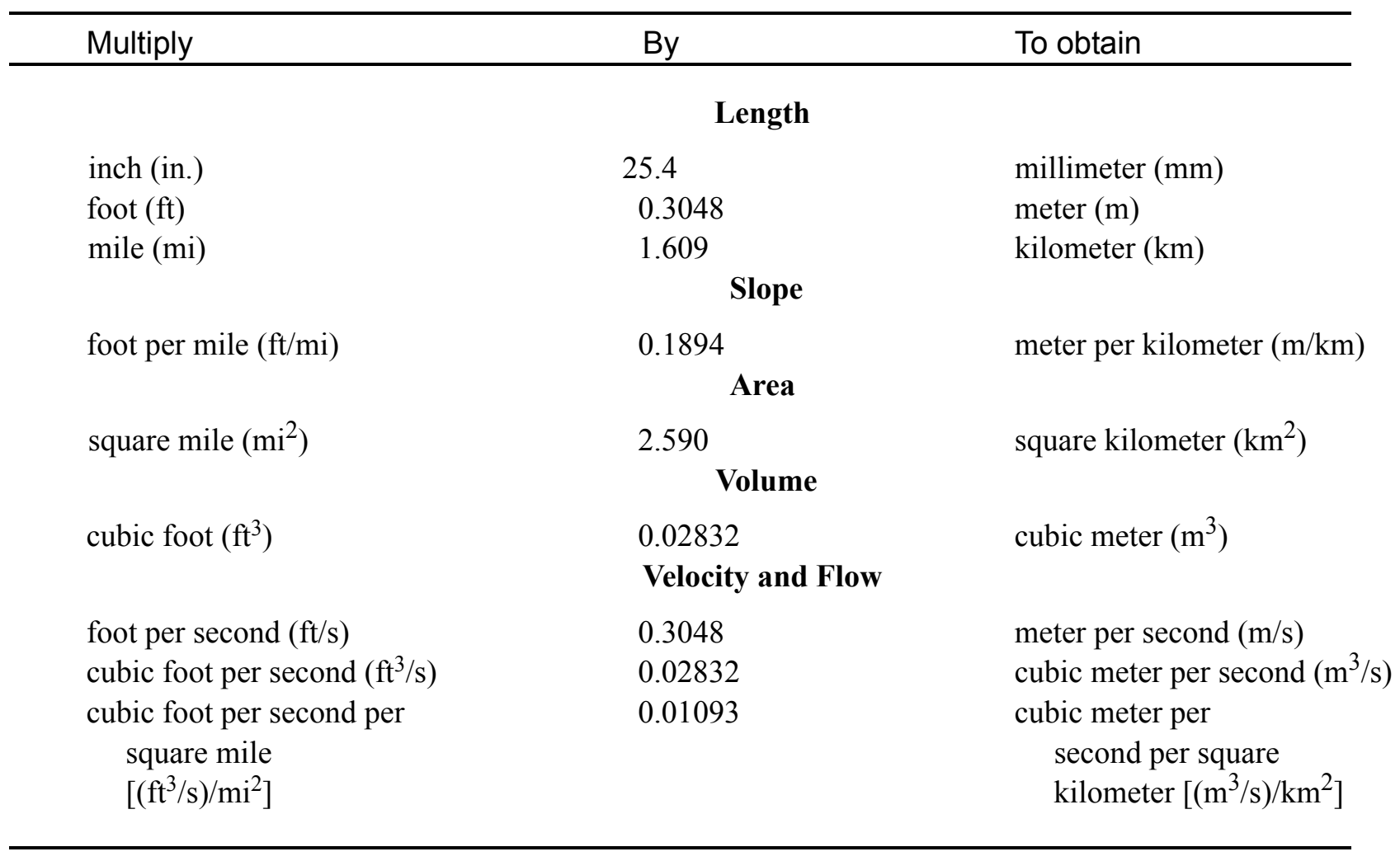

\section{OTHER ABBREVIATIONS}

$\begin{array}{lrlr}\mathrm{BF} & \text { bank full } & \text { LWW } & \text { left wingwall } \\ \mathrm{cfs} & \text { cubic feet per second } & \text { MC } & \text { main channel } \\ \mathrm{D}_{50} & \text { median diameter of bed material } & \text { RAB } & \text { right abutment } \\ \mathrm{DS} & \text { downstream } & \text { RABUT } & \text { face of right abutment } \\ \mathrm{elev} & \text { elevation } & \text { RB } & \text { right bank } \\ \mathrm{f} / \mathrm{p} & \text { flood plain } & \text { ROB } & \text { right overbank } \\ \mathrm{ft}^{2} & \text { square feet } & \text { RWW } & \text { right wingwall } \\ \mathrm{ft} / \mathrm{ft} & \text { feet per foot } & \text { TH } & \text { town highway } \\ \mathrm{JCT} & \text { junction } & \text { UB } & \text { under bridge } \\ \mathrm{LAB} & \text { left abutment } & \text { US } & \text { upstream } \\ \mathrm{LABUT} & \text { face of left abutment } & \text { USGS } & \text { United States Geological Survey } \\ \mathrm{LB} & \text { left bank } & \text { VTAOT Vermont Agency of Transportation } \\ \mathrm{LOB} & \text { left overbank } & \text { WSPRO } & \text { water-surface profile model }\end{array}$

In this report, the words "right" and "left" refer to directions that would be reported by an observer facing downstream. Sea level: In this report, "sea level" refers to the National Geodetic Vertical Datum of 1929-- a geodetic datum derived from a general adjustment of the first-order level nets of the United States and Canada, formerly called Sea Level Datum of 1929.

In the appendices, the above abbreviations may be combined. For example, USLB would represent upstream left bank. 


\title{
LEVEL II SCOUR ANALYSIS FOR BRIDGE 8 (WELLTH00020008) ON TOWN HIGHWAY 2, CROSSING WELLS BROOK, WELLS, VERMONT
}

\author{
By Lora K. Striker and Michael A. Ivanoff
}

\section{INTRODUCTION AND SUMMARY OF RESULTS}

This report provides the results of a detailed Level II analysis of scour potential at structure WELLTH00020008 on Town Highway 2 crossing the Wells Brook, Wells, Vermont (figures 1-8). A Level II study is a basic engineering analysis of the site, including a quantitative analysis of stream stability and scour (U.S. Department of Transportation, 1993). Results of a Level I scour investigation also are included in Appendix E of this report. A Level I investigation provides a qualitative geomorphic characterization of the study site. Information on the bridge, gleaned from Vermont Agency of Transportation (VTAOT) files, was compiled prior to conducting Level I and Level II analyses and is found in Appendix D.

The site is in the Taconic section of the New England physiographic province in southwestern Vermont. The 14.4- $\mathrm{mi}^{2}$ drainage area is in a predominantly rural and forested basin. In the vicinity of the study site, the surface cover on the right overbanks is predominantly suburban while the immediate banks are vegetated with trees and brush. The left bank upstream and downstream is predominantly pasture.

In the study area, the Wells Brook has an incised, straight channel with a slope of approximately $0.005 \mathrm{ft} / \mathrm{ft}$, an average channel top width of $51 \mathrm{ft}$ and an average bank height of $7 \mathrm{ft}$. The channel bed material ranges from gravel to boulder with a median grain size $\left(\mathrm{D}_{50}\right)$ of $48.6 \mathrm{~mm}(0.159 \mathrm{ft})$. The geomorphic assessment at the time of the Level I and Level II site visit on September 19, 1995, indicated that the reach was stable.

The Town Highway 2 crossing of the Wells Brook is a 35-ft-long, two-lane bridge consisting of one 32-foot concrete span (Vermont Agency of Transportation, written communication, March 22, 1995). The opening length of the structure parallel to the bridge face is $31.7 \mathrm{ft}$. The bridge is supported by vertical, concrete abutments with wingwalls. The channel is skewed approximately 10 degrees to the opening while the opening-skew-toroadway is 5 degrees. 
A scour hole $1.5 \mathrm{ft}$ deeper than the mean thalweg depth was observed along the left abutment during the Level I assessment. The only scour protection measure at the site was type- 2 stone fill (less than 36 inches diameter) along the left bank upstream, and type-5 (placed stone wall) at the upstream end of the upstream left wingwall, at the downstream end of the downstream left wingwall, and along the downstream left bank. Additional details describing conditions at the site are included in the Level II Summary and Appendices D and E.

Scour depths and recommended rock rip-rap sizes were computed using the general guidelines described in Hydraulic Engineering Circular 18 (Richardson and others, 1995) for the 100- and 500-year discharges. In addition, the incipient roadway-overtopping discharge is determined and analyzed as another potential worst-case scour scenario. Total scour at a highway crossing is comprised of three components: 1) long-term streambed degradation; 2) contraction scour (due to accelerated flow caused by a reduction in flow area at a bridge) and; 3) local scour (caused by accelerated flow around piers and abutments). Total scour is the sum of the three components. Equations are available to compute depths for contraction and local scour and a summary of the results of these computations follows.

Contraction scour for all modelled flows ranged from 0.0 to $0.8 \mathrm{ft}$. The worst-case contraction scour occurred at the incipient roadway-overtopping discharge, which was less than the 100-year discharge. Abutment scour ranged from 5.6 to $10.0 \mathrm{ft}$ at the left abutment and from 3.1 to $4.2 \mathrm{ft}$ at the right abutment. The worst-case abutment scour occurred at the incipient roadway-overtopping discharge at the left abutment. Additional information on scour depths and depths to armoring are included in the section titled "Scour Results". Scoured-streambed elevations, based on the calculated scour depths, are presented in tables 1 and 2. A cross-section of the scour computed at the bridge is presented in figure 8. Scour depths were calculated assuming an infinite depth of erosive material and a homogeneous particle-size distribution.

Usually, computed scour depths are evaluated in combination with other information including (but not limited to) historical performance during flood events, the geomorphic stability assessment, existing scour protection measures, and the results of the hydraulic analyses. Therefore, scour depths adopted by VTAOT may differ from the computed values documented herein. 


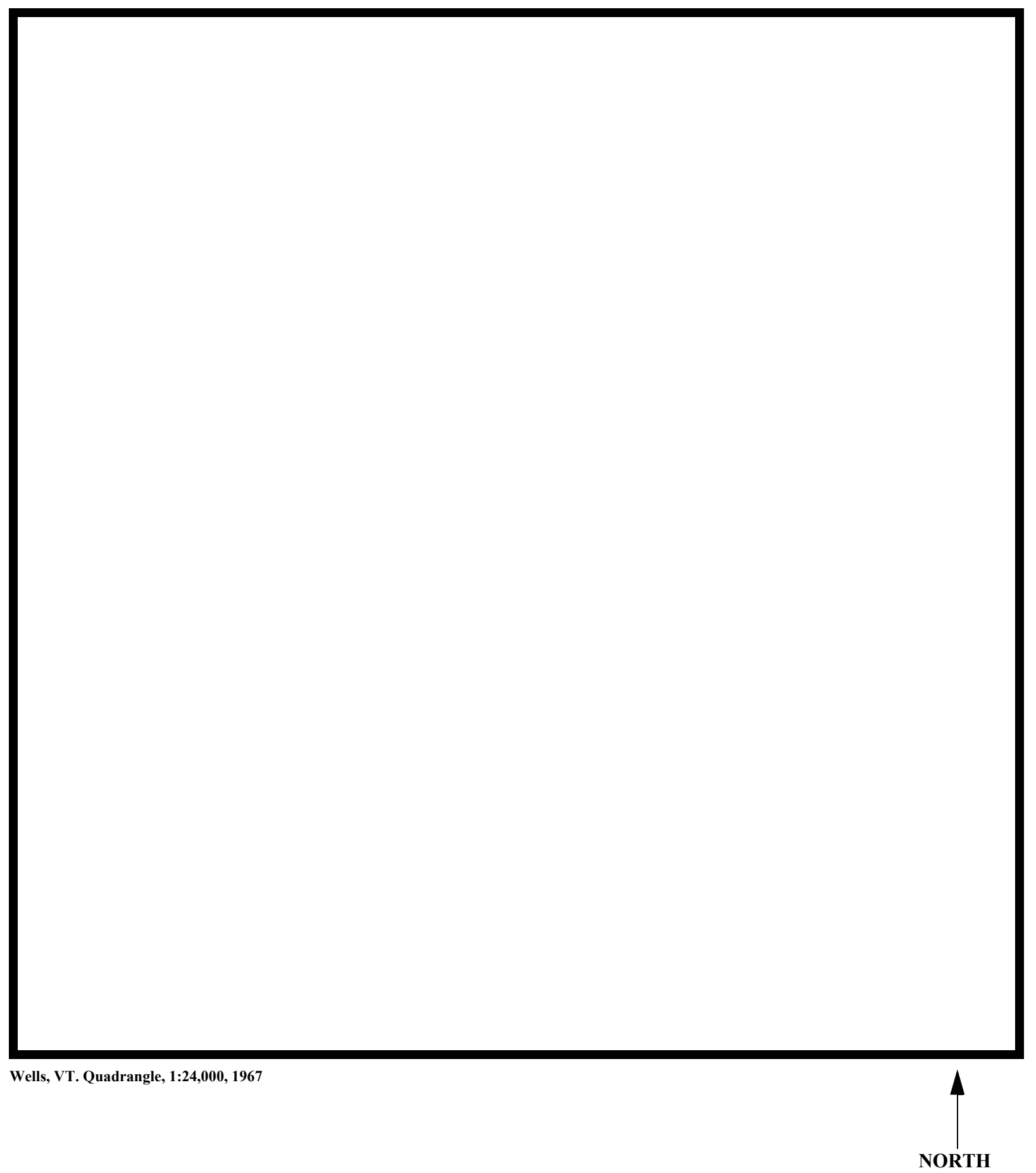

Figure 1. Location of study area on USGS 1:24,000 scale map. 
Figure 2. Location of study area on Vermont Agency of Transportation town highway map. 

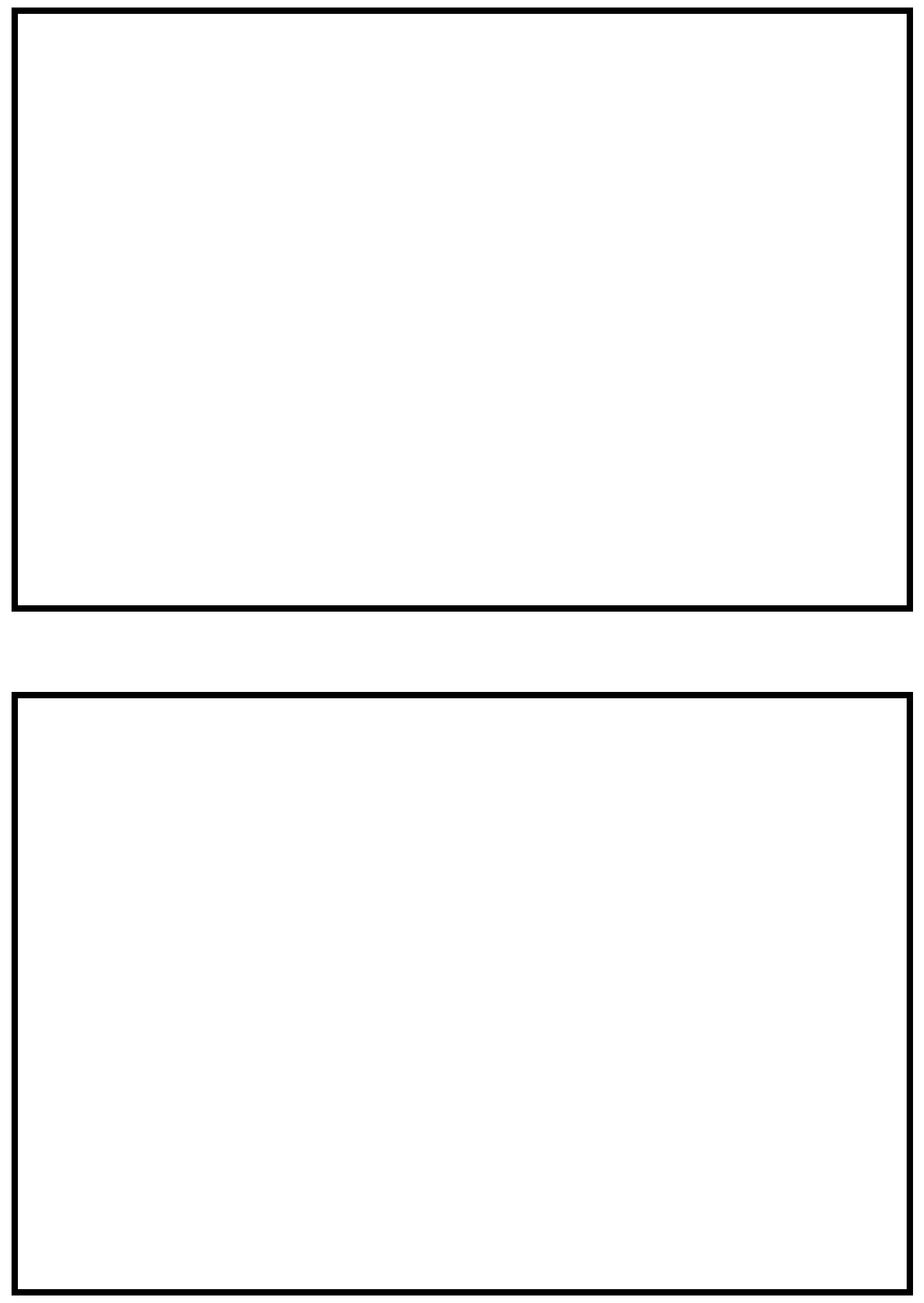

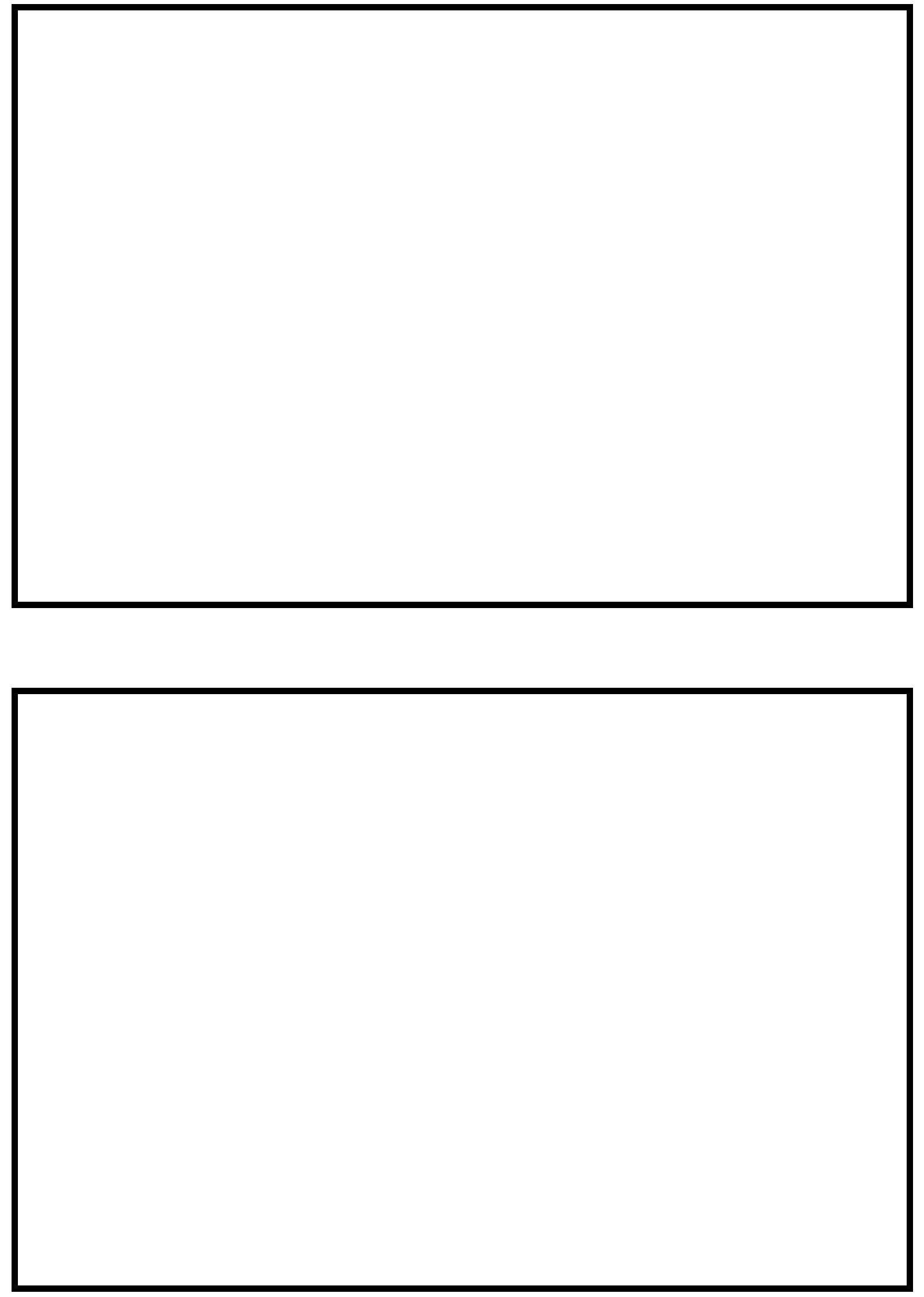


\section{LEVEL II SUMMARY}

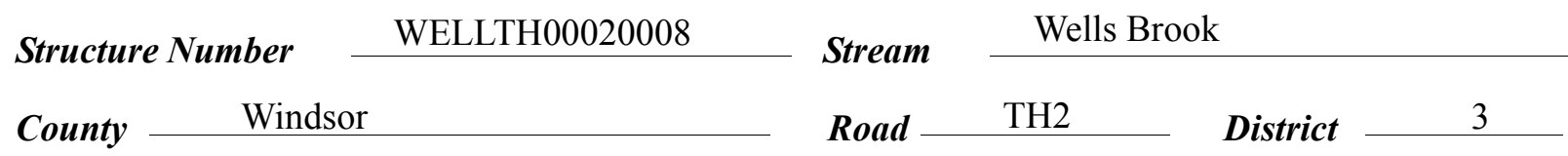

\section{Description of Bridge}

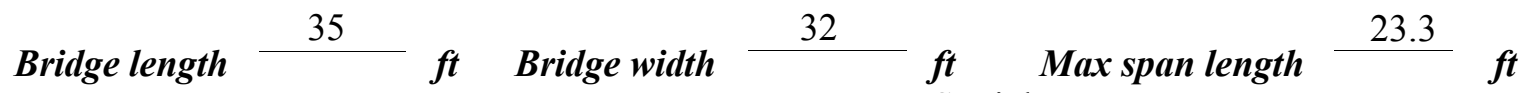
Alignment of bridge to road (on curve or straight)

Abutment type Vertical, concrete

Stone fill on abutment?

\section{Embankment type} Straight
Sloping

09/19/95

namanintin... af ata... n fill

Dato af incnortion Type-5, stone walls, one located at the upstream end of the upstream left wingwall and one located at the downstream end of the downstream left wingwall.

The abutments and wingwalls are concrete. There is a $1.5 \mathrm{ft}$ deep scour hole in front of the left abutment. The left abutment footing is exposed $4.0 \mathrm{ft}$ while the right abutment footing is exposed $2.2 \mathrm{ft}$. Yes

\section{5} No

Is bridge skewed to flood flow according to 'survey? Angle

$09 / 19 / 95$

Debris accumulation on bridge at time of Level I or Level II site visit:

\begin{tabular}{|c|c|c|c|}
\hline & $\begin{array}{c}\text { Date of incnortion } \\
\underline{0}\end{array}$ & $\begin{array}{l}\text { Percent of rhmunal } \\
\text { blocked inortzontatly }\end{array}$ & $\begin{array}{l}\text { Percent of } 09 / 19 / 1 e l \\
\text { blocked verticatty }\end{array}$ \\
\hline & $\underline{95}$ & 0 & 0 \\
\hline $\begin{array}{l}\text { Level II } \\
\text { trees. }\end{array}$ & Moderate. & bank upstream are stabl & avily vegetated with \\
\hline
\end{tabular}

None as of 09/19/95.

Dosriho anv, fonturos noar ar at tho hridoo that mav affort flow, (includo ahsorvation dato) 


\section{Description of the Geomorphic Setting}

General topography The channel is located within a low relief valley with a flat to slightly irregular flood plain.

Geomorphic conditions at bridge site: downstream (DS), upstream (US)

Date of inspection $\quad 09 / 19 / 95$

DS left: $\quad$ Steep channel bank to flood plain

DS right: $\quad$ Steep channel bank to flood plain

US left: $\quad$ Steep channel bank to flood plain

US right: $\quad$ Steep channel bank to flood plain

\section{Description of the Channel}

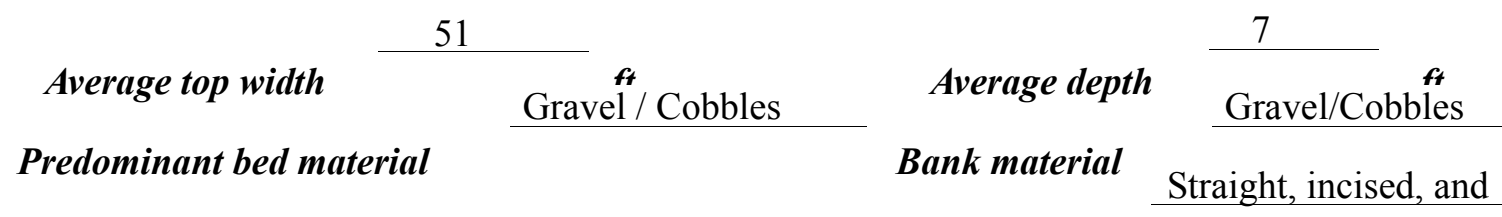

stable with semi-alluvial channel boundaries and no braiding nö anabranching.

$09 / 19 / 95$

Vegetative co 1 Placed stone wall to yard and house on overbank

DS left: $\quad$ Trees and brush

DS right: $\quad$ Brush and a few trees with pasture on the overbank

US left: $\quad$ Trees and brush

US right: $\quad$ Yes

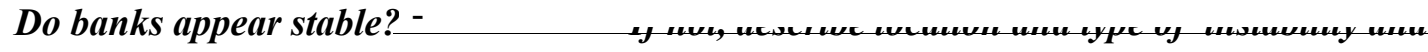

date of observatton.

None as of $09 / 19 / 95$.

Describe any obstructions in channel and date of observation. 


\title{
Hydrology
}

Drainage area $\frac{14.4}{m^{2}}{ }^{2}$

Percentage of drainage area in physiographic provinces: (approximate)

Physiographic province/section

New England/Taconic Section
Percent of drainage area 100

\begin{abstract}
Is drainage area considered rural or urban? Rural Describe any significant urbanization: None.
\end{abstract}

Is there a USGS gage on the stream of interest?

No

\section{USGS gage description}

USGS gage number

Gage drainage area $\mathrm{mi}^{2}$

Is there a lake/p

\section{Calculated Discharges $\quad \underline{3,050}$ \\ Q100 $\quad \mathrm{ft}^{3} / \mathrm{s}$ \\ Q500 $\quad \mathrm{ft}^{3} / \mathrm{s}$}

The 100- and 500-year discharges are based on the 500-year discharge (Benson, 1962; Johnson and Tasker, 1974; FHWA, 1983; Potter, 1957a\&b; Talbot, 1887). 


\section{Description of the Water-Surface Profile Model (WSPRO) Analysis}

Datum for WSPRO analysis (USGS survey, sea level, VTAOT plans)

USGS survey

Datum tie between USGS survey and VTAOT plans

None.

Description of reference marks used to determine USGS datum. $\quad$ RM1 is a chiseled X

inside a chiseled square on top of the upstream end of the left abutment (elev. $501.57 \mathrm{ft}$, arbitrary

survey datum). RM2 is the center point of a chiseled $\mathrm{X}$ in top of concrete on the downstream

end of the right abutment (elev. $501.60 \mathrm{ft}$, arbitrary survey datum).

\section{Cross-Sections Used in WSPRO Analysis}

\begin{tabular}{cccl}
\hline${ }^{1}$ Cross-section & $\begin{array}{c}\text { Section } \\
\text { Reference } \\
\text { Distance } \\
\text { (SRD) in feet }\end{array}$ & $\begin{array}{c}{ }^{2} \text { Cross-section } \\
\text { development }\end{array}$ & \multicolumn{1}{c}{ Comments } \\
\hline EXITX & -29 & 1 & $\begin{array}{l}\text { Exit section } \\
\text { Downstream Full-valley } \\
\text { section (Templated from } \\
\text { EXITX) }\end{array}$ \\
BRIDG & 0 & 2 & $\begin{array}{l}\text { Bridge section } \\
\text { Road Grade section } \\
\text { RDWAY }\end{array}$ \\
APPRO & 12 & 1 & $\begin{array}{l}\text { Approach section as sur- } \\
\text { veyed. }\end{array}$ \\
\hline
\end{tabular}

${ }^{1}$ For location of cross-sections see plan-view sketch included with Level I field form, Appendix E. For more detail on how cross-sections were developed see WSPRO input file. 


\section{Data and Assumptions Used in WSPRO Model}

Hydraulic analyses of the reach were done by use of the Federal Highway Administration's WSPRO step-backwater computer program (Shearman and others, 1986, and Shearman, 1990). The analyses reported herein reflect conditions existing at the site at the time of the study. Furthermore, in the development of the model it was necessary to assume no accumulation of debris or ice at the site. Results of the hydraulic model are presented in the Bridge Hydraulic Summary, Appendix B, and figure 7.

Channel roughness factors (Manning's “ $n$ ”) used in the hydraulic model were estimated using field inspections at each cross section following the general guidelines described by Arcement and Schneider (1989). Final adjustments to the values were made during the modelling of the reach. Channel " $n$ " values for the reach ranged from 0.040 to 0.045 , and overbank " $n$ " values ranged from 0.045 to 0.060 .

Normal depth at the exit section (EXITX) was assumed as the starting water surface. This depth was computed by use of the slope-conveyance method outlined in the user's manual for WSPRO (Shearman, 1990). The slope used was $0.005 \mathrm{ft} / \mathrm{ft}$, which was computed from survey points taken downstream of the bridge site on September 19, 1995.

The surveyed approach section (APPRO) was taken one bridge length upstream of the upstream face to establish the modelled approach section as recommended by Shearman and others (1986). This location provides a consistent method for determining scour variables. 


\section{Bridge Hydraulics Summary}

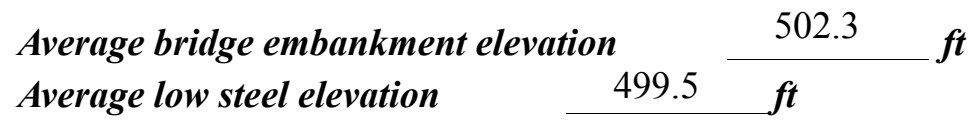

100-year discharge $\quad 2,500 \quad \mathrm{ft}^{3} / \mathrm{s}$

Water-surface elevation in bridge opening $\quad 499.6 \quad f t$

Road overtopping? ___ Yes Discharge over road __ $364 \quad \mathrm{ft}^{3} / \mathrm{s}$

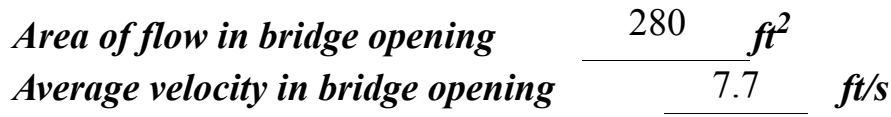

$\begin{array}{lll}\text { Maximum WSPRO tube velocity at bridge } & 9.7 \quad \mathrm{ft} / \mathrm{s}\end{array}$

Water-surface elevation at Approach section with bridge $\quad 500.7$

Water-surface elevation at Approach section without bridge $\quad \overline{499.0}$

Amount of backwater caused by bridge

1.7 it

500-year discharge $\quad 3,050 \quad \mathrm{ft}^{3} / \mathrm{s}$

Water-surface elevation in bridge opening $499.6 \mathrm{ft}$

Road overtopping? ___ Yes Discharge over road _ $\quad$ _ $670 \quad \ldots 3 / s$

Area of flow in bridge opening $\quad 281 \quad \mathrm{ft}^{2}$

Average velocity in bridge opening $8.4 \mathrm{ft} / \mathrm{s}$

Maximum WSPRO tube velocity at bridge $\quad 9.9$ 's

Water-surface elevation at Approach section with bridge $\quad 501.0$

Water-surface elevation at Approach section without bridge $\quad 499.6$

Amount of backwater caused by bridge $\quad 1.4$,t

Incipient overtopping discharge $\quad 2,470 \quad \mathrm{ft}^{3} / \mathrm{s}$

Water-surface elevation in bridge opening $498.0 \quad$ it

Area of flow in bridge opening $\quad 235 \quad \mathrm{ft}^{2}$

Average velocity in bridge opening $\quad 10.5 \quad \mathrm{ft} / \mathrm{s}$

Maximum WSPRO tube velocity at bridge $13.1 \mathrm{ft} / \mathrm{s}$

Water-surface elevation at Approach section with bridge

Water-surface elevation at Approach section without bridge

499.7

Amount of backwater caused by bridge $\quad 0.8$.t

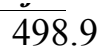




\section{Scour Analysis Summary}

\section{Special Conditions or Assumptions Made in Scour Analysis}

Scour depths were computed using the general guidelines described in Hydraulic Engineering Circular 18 (Richardson and others, 1995). Scour depths were calculated assuming an infinite depth of erosive material and a homogeneous particle-size distribution.

Contraction scour for the incipient roadway-overtopping discharge was computed by use of the Laursen clear-water contraction scour equation (Richardson and others, 1995, p. 32 , equation 20). At this site, the 100-year and 500-year discharges resulted in unsubmerged orifice flow. Contraction scour at bridges with orifice flow is best estimated by use of the Chang pressure-flow scour equation (oral communication, J. Sterling Jones, October 4, 1996). Thus, contraction scour for these discharges was computed by use of the Chang equation (Richardson and others, 1995, p. 145-146). The results of the scour analysis are presented in tables 1 and 2 and a graph of the scour depths is presented in figure 8 . The streambed armoring depths computed suggest that armoring will not limit the depth of contraction scour.

For comparison, contraction scour for the discharges resulting in orifice flow was also computed by use of the Laursen clear-water contraction scour equation and the Umbrell pressure-flow equation (Richardson and others, 1995, p. 144) and is presented in Appendix F. Furthermore, for those discharges resulting in unsubmerged orifice flow, contraction scour was computed by substituting estimates for the depth of flow at the downstream bridge face in the contraction scour equations. Results with respect to these substitutions are provided in Appendix F.

Abutment scour was computed by use of the HIRE equation (Richardson and others, 1995, p. 49, equation 29) because the HIRE equation is recommended when the length to depth ratio of the embankment blocking flow exceeds 25. Variables for the HIRE equation include the Froude number of the flow approaching the embankments, the length of the embankment blocking flow, and the depth of flow approaching the embankment less any roadway overtopping. 


\section{Scour Results}

100-yr discharge 500-yr discharge

Contraction scour:

(Scour depths in feet)

Main channel

Live-bed scour

Clear-water scour

Depth to armoring

Left overbank

Right overbank

Local scour:

Abutment scour

Left abutment

5.6

6.5

10.0

4.2

$4.2-$

$3.1-$

\section{Right abutment}

Pier scour

Pier 1

Pier 2

Pier 3

Abutments:

Left abutment

Right abutment

Piers:

Pier 1

Pier 2

overtopping discharge 


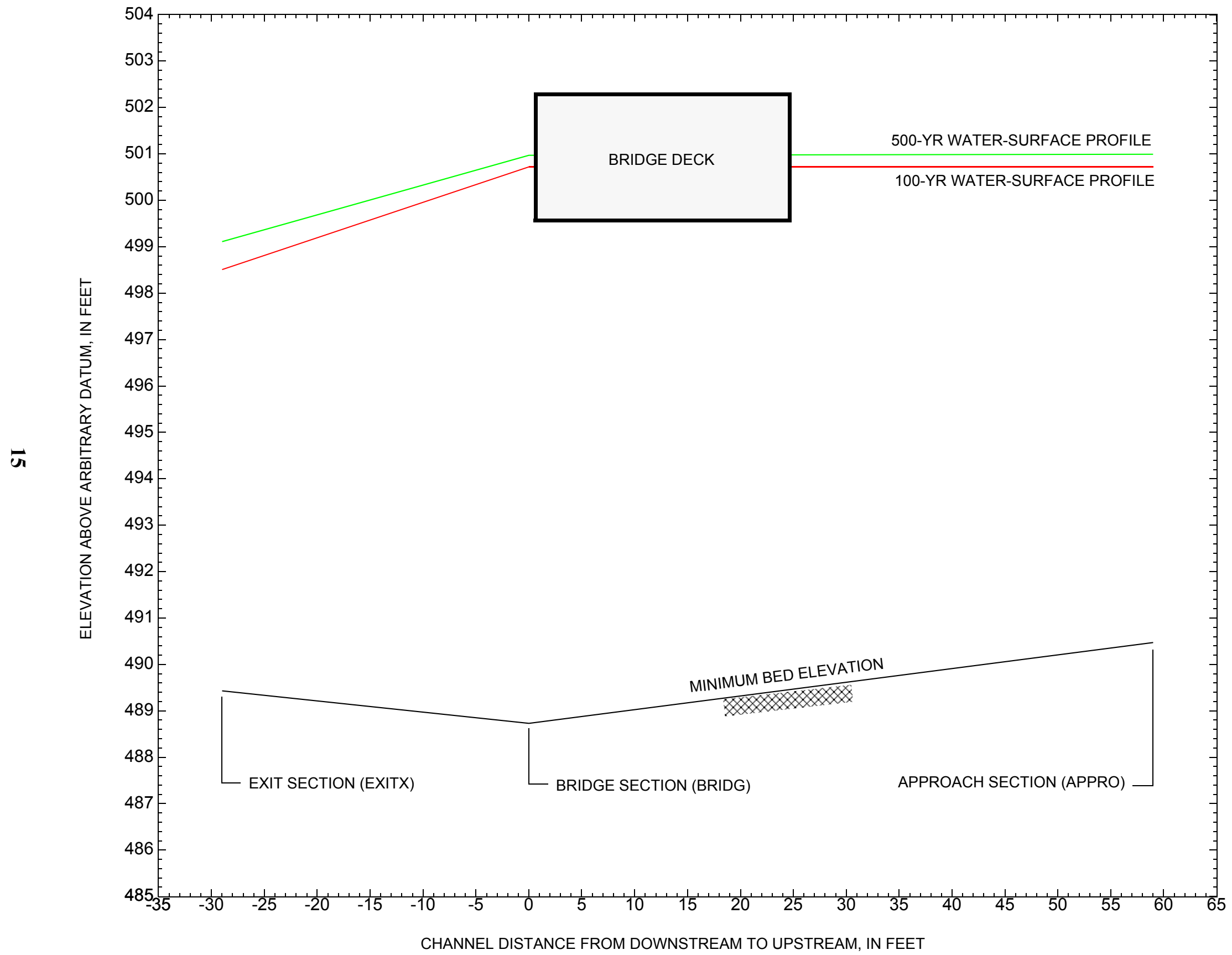

Figure 7. Water-surface profiles for the 100-year and 500-year discharges at structure WELLTH00020008 on Town Highway 2, crossing Wells Brook, Wells, Vermont. 


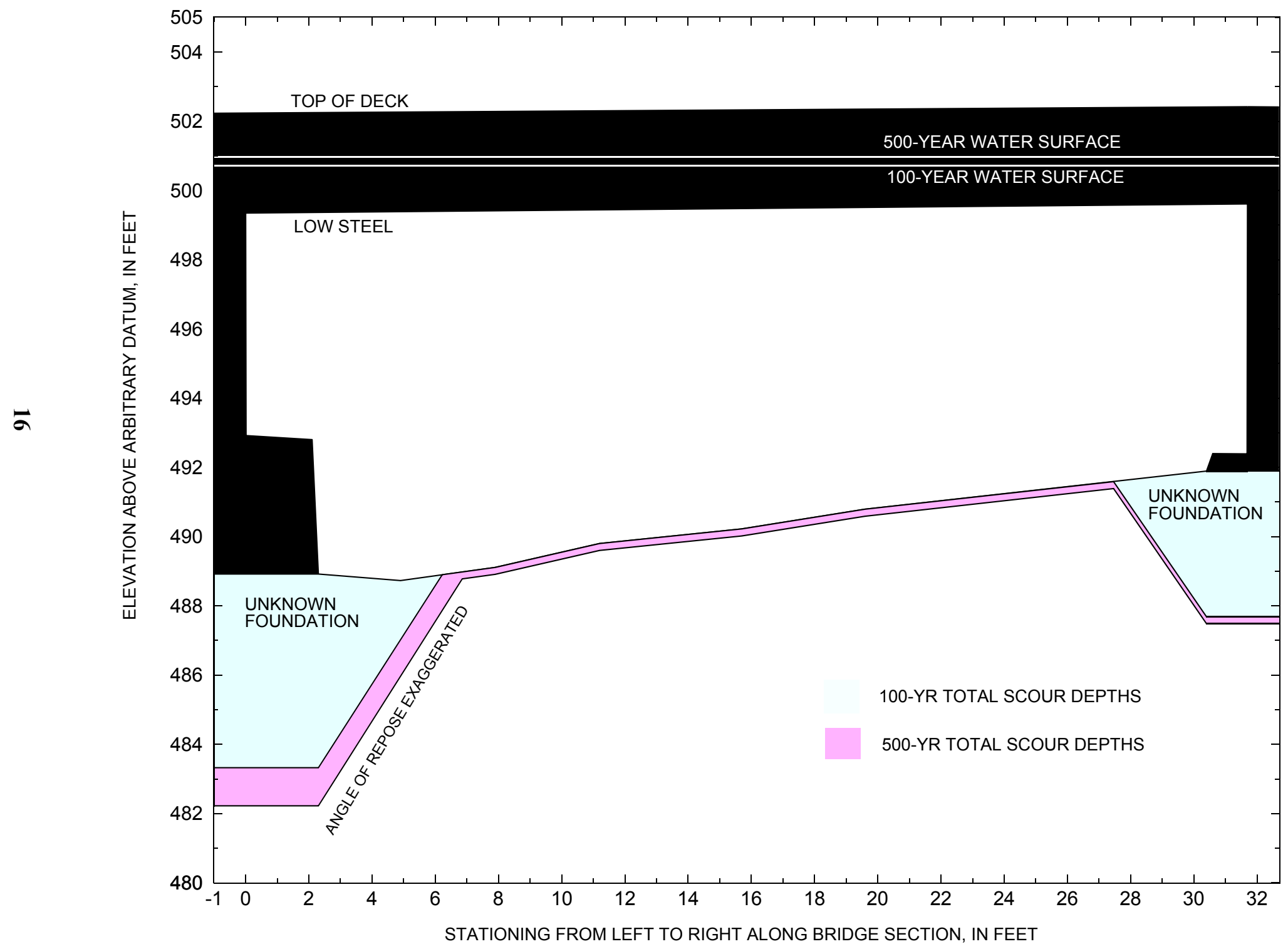

Figure 8. Scour elevations for the 100-year and 500-year discharges at structure WELLTH00020008 on Town Highway 2, crossing Wells Brook, Wells, Vermont. 


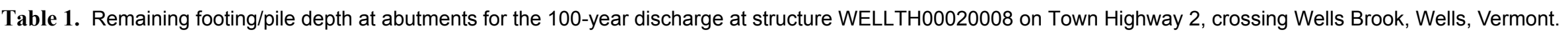
[VTAOT, Vermont Agency of Transportation; --, no data]

\begin{tabular}{|c|c|c|c|c|c|c|c|c|c|c|c|}
\hline Description & Station $^{1}$ & $\begin{array}{l}\text { VTAOT } \\
\text { minimum } \\
\text { low-chord } \\
\text { elevation } \\
\text { (feet) }\end{array}$ & $\begin{array}{l}\text { Surveyed } \\
\text { minimum } \\
\text { low-chord } \\
\text { elevation }{ }^{2} \\
\text { (feet) }\end{array}$ & $\begin{array}{c}\text { Bottom of } \\
\text { footing/pile } \\
\text { elevation }{ }^{2} \\
\text { (feet) }\end{array}$ & $\begin{array}{c}\text { Channel } \\
\text { elevation at } \\
\text { abutment/ } \\
\text { pier }^{2} \\
\text { (feet) }\end{array}$ & $\begin{array}{l}\text { Contraction } \\
\text { scour depth } \\
\text { (feet) }\end{array}$ & $\begin{array}{l}\text { Abutment } \\
\text { scour } \\
\text { depth } \\
\text { (feet) }\end{array}$ & $\begin{array}{l}\text { Pier } \\
\text { scour } \\
\text { depth } \\
\text { (feet) }\end{array}$ & $\begin{array}{l}\text { Depth of } \\
\text { total scour } \\
\text { (feet) }\end{array}$ & $\begin{array}{c}\text { Elevation of } \\
\text { scour }^{2} \\
\text { (feet) }\end{array}$ & $\begin{array}{c}\text { Remaining } \\
\text { footing/pile } \\
\text { depth } \\
\text { (feet) }\end{array}$ \\
\hline \multicolumn{12}{|c|}{100 -yr. discharge is 2,500 cubic-feet per second } \\
\hline $\begin{array}{l}\text { Left abutment } \\
\text { footing }\end{array}$ & 0.0 & -- & 499.4 & -- & 488.9 & 0.0 & 5.6 & -- & 5.6 & 483.3 & -- \\
\hline $\begin{array}{l}\text { Right abutment } \\
\text { footing }\end{array}$ & 31.7 & -- & 499.6 & -- & 491.9 & 0.0 & 4.2 & -- & 4.2 & 487.7 & -- \\
\hline
\end{tabular}

1.Measured along the face of the most constricting side of the bridge.

2.Arbitrary datum for this study.

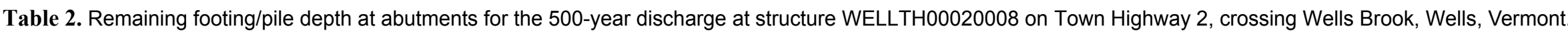
[VTAOT, Vermont Agency of Transportation; --, no data]

\begin{tabular}{|c|c|c|c|c|c|c|c|c|c|c|c|}
\hline Description & Station $^{1}$ & $\begin{array}{l}\text { VTAOT } \\
\text { minimum } \\
\text { low-chord } \\
\text { elevation } \\
\text { (feet) }\end{array}$ & $\begin{array}{l}\text { Surveyed } \\
\text { minimum } \\
\text { low-chord } \\
\text { elevation } \\
\text { (feet) }\end{array}$ & $\begin{array}{l}\text { Bottom of } \\
\text { footing/pile } \\
\text { elevation } \\
\text { (feet) }\end{array}$ & $\begin{array}{c}\text { Channel } \\
\text { elevation at } \\
\text { abutment/ } \\
\text { pier }^{2} \\
\text { (feet) }\end{array}$ & $\begin{array}{l}\text { Contraction } \\
\text { scour depth } \\
\text { (feet) }\end{array}$ & $\begin{array}{l}\text { Abutment } \\
\text { scour } \\
\text { depth } \\
\text { (feet) }\end{array}$ & $\begin{array}{l}\text { Pier } \\
\text { scour } \\
\text { depth } \\
\text { (feet) }\end{array}$ & $\begin{array}{l}\text { Depth of } \\
\text { total scour } \\
\text { (feet) }\end{array}$ & $\begin{array}{c}\text { Elevation of } \\
\text { scour }^{2} \\
\text { (feet) }\end{array}$ & $\begin{array}{c}\text { Remaining } \\
\text { footing/pile } \\
\text { depth } \\
\text { (feet) }\end{array}$ \\
\hline \multicolumn{12}{|c|}{500 -yr. discharge is 3,050 cubic-feet per second } \\
\hline $\begin{array}{l}\text { Left abutment } \\
\text { footing }\end{array}$ & 0.0 & -- & 499.4 & -- & 488.9 & 0.2 & 6.5 & -- & 6.7 & 482.2 & -- \\
\hline $\begin{array}{l}\text { Right abutment } \\
\text { footing }\end{array}$ & 31.7 & -- & 499.6 & -- & 491.9 & 0.2 & 4.2 & -- & 4.4 & 487.5 & -- \\
\hline
\end{tabular}

1.Measured along the face of the most constricting side of the bridge.

2.Arbitrary datum for this study. 


\section{SELECTED REFERENCES}

Arcement, G.J., Jr., and Schneider, V.R., 1989, Guide for selecting Manning's roughness coefficients for natural channels and flood plains: U.S. Geological Survey Water-Supply Paper 2339, 38 p.

Barnes, H.H., Jr., 1967, Roughness characteristics of natural channels: U.S. Geological Survey Water-Supply Paper 1849,213 p.

Benson, M. A., 1962, Factors Influencing the Occurrence of Floods in a Humid Region of Diverse Terrain: U.S. Geological Survey WaterSupply Paper 1580-B, 64 p.

Brown, S.A. and Clyde, E.S., 1989, Design of riprap revetment: Federal Highway Administration Hydraulic Engineering Circular No. 11, Publication FHWA-IP-89-016, 156 p.

Federal Highway Administration, 1983, Runoff estimates for small watersheds and development of sound design: Federal Highway Administration Report FHWA-RD-77-158.

Federal Highway Administration, 1993, Stream Stability and Scour at Highway Bridges: Participant Workbook: Federal Highway Administration Report FHWA-HI-91-011.

Froehlich, D.C., 1989, Local scour at bridge abutments in Ports, M.A., ed., Hydraulic Engineering--Proceedings of the 1989 National Conference on Hydraulic Engineering: New York, American Society of Civil Engineers, p. 13-18.

Hayes, D.C.,1993, Site selection and collection of bridge-scour data in Delaware, Maryland, and Virginia: U.S. Geological Survey WaterResources Investigation Report 93-4017, 23 p.

Interagency Advisory Committee on Water Data, 1982, Guidelines for determining flood flow frequency: U.S. Geological Survey, Bulletin 17B of the Hydrology Subcommittee, 190 p.

Johnson, C.G. and Tasker, G.D.,1974, Progress report on flood magnitude and frequency of Vermont streams: U.S. Geological Survey OpenFile Report 74-130, 37 p.

Lagasse, P.F., Schall, J.D., Johnson, F., Richardson, E.V., Chang, F., 1995, Stream Stability at Highway Structures: Federal Highway Administration Hydraulic Engineering Circular No. 20, Publication FHWA-IP-90-014, 144 p.

Laursen, E.M., 1960, Scour at bridge crossings: Journal of the Hydraulics Division, American Society of Civil Engineers, v. 86, no. HY2, p. 39-53.

Potter, W. D., 1957a, Peak rates of runoff in the Adirondack, White Mountains, and Maine woods area, Bureau of Public Roads

Potter, W. D., 1957b, Peak rates of runoff in the New England Hill and Lowland area, Bureau of Public Roads

Richardson, E.V. and Davis, S.R., 1995, Evaluating scour at bridges: Federal Highway Administration Hydraulic Engineering Circular No. 18, Publication FHWA-IP-90-017, 204 p.

Richardson, E.V., Simons, D.B., and Julien, P.Y., 1990, Highways in the river environment: Federal Highway Administration Publication FHWA-HI-90-016.

Ritter, D.F., 1984, Process Geomorphology: W.C. Brown Co., Debuque, Iowa, 603 p.

Shearman, J.O., 1990, User's manual for WSPRO--a computer model for water surface profile computations: Federal Highway Administration Publication FHWA-IP-89-027, 187 p.

Shearman, J.O., Kirby, W.H., Schneider, V.R., and Flippo, H.N., 1986, Bridge waterways analysis model; research report: Federal Highway Administration Publication FHWA-RD-86-108, 112 p.

Talbot, A.N., 1887, The determination of water-way for bridges and culverts.

U.S. Department of Transportation, 1993, Stream stability and scour at highway bridges, Participant Workbook: Federal Highway Administration Publication FHWA HI-91-011.

U.S. Geological Survey, 1967, Wells, Vermont 7.5 Minute Series quadrangle map: U.S. Geological Survey Topographic Maps, Scale 1:24,000. 


\section{APPENDIX A: \\ WSPRO INPUT FILE}




\section{WSPRO INPUT FILE}

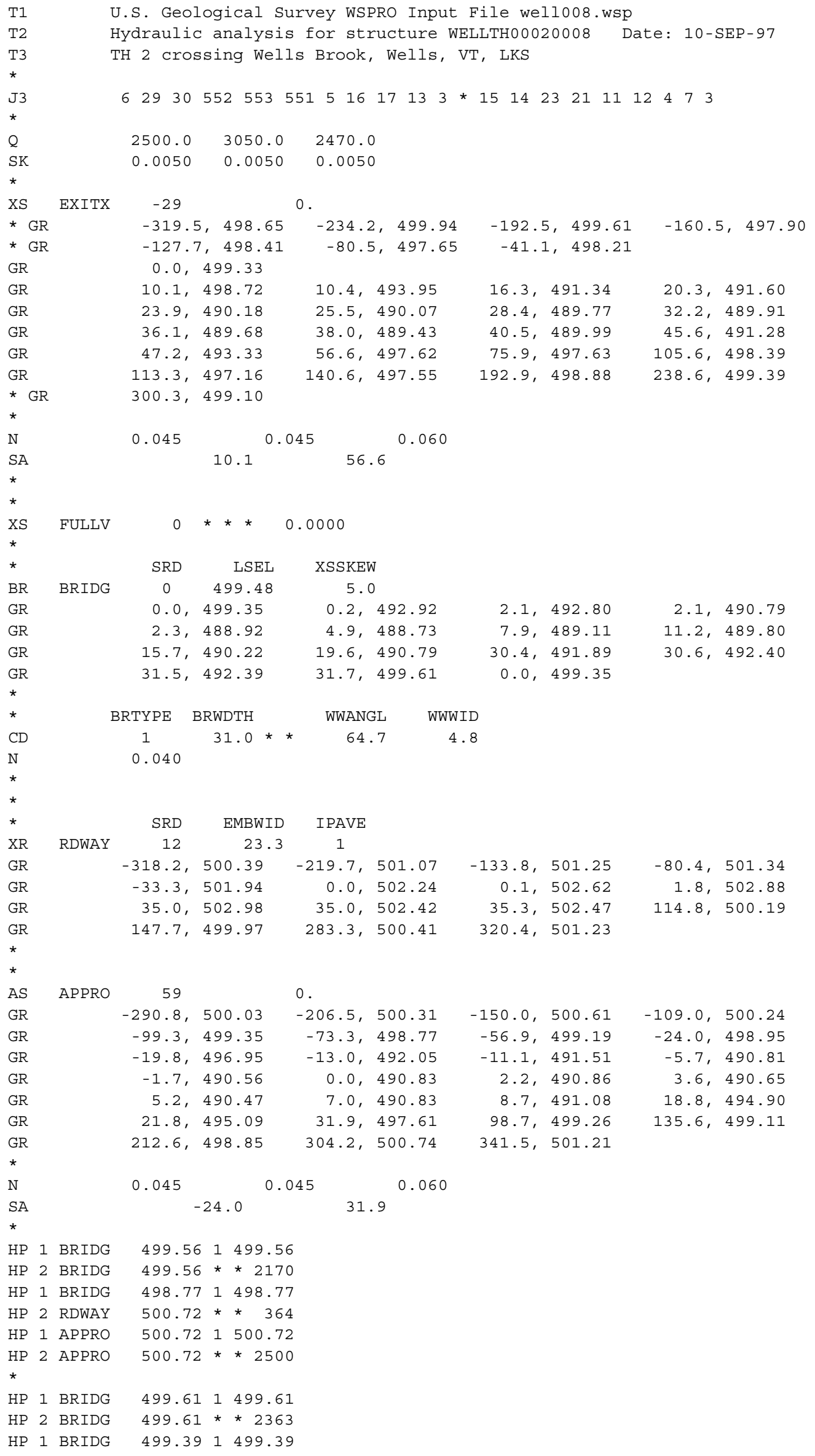




\section{APPENDIX B: \\ WSPRO OUTPUT FILE}




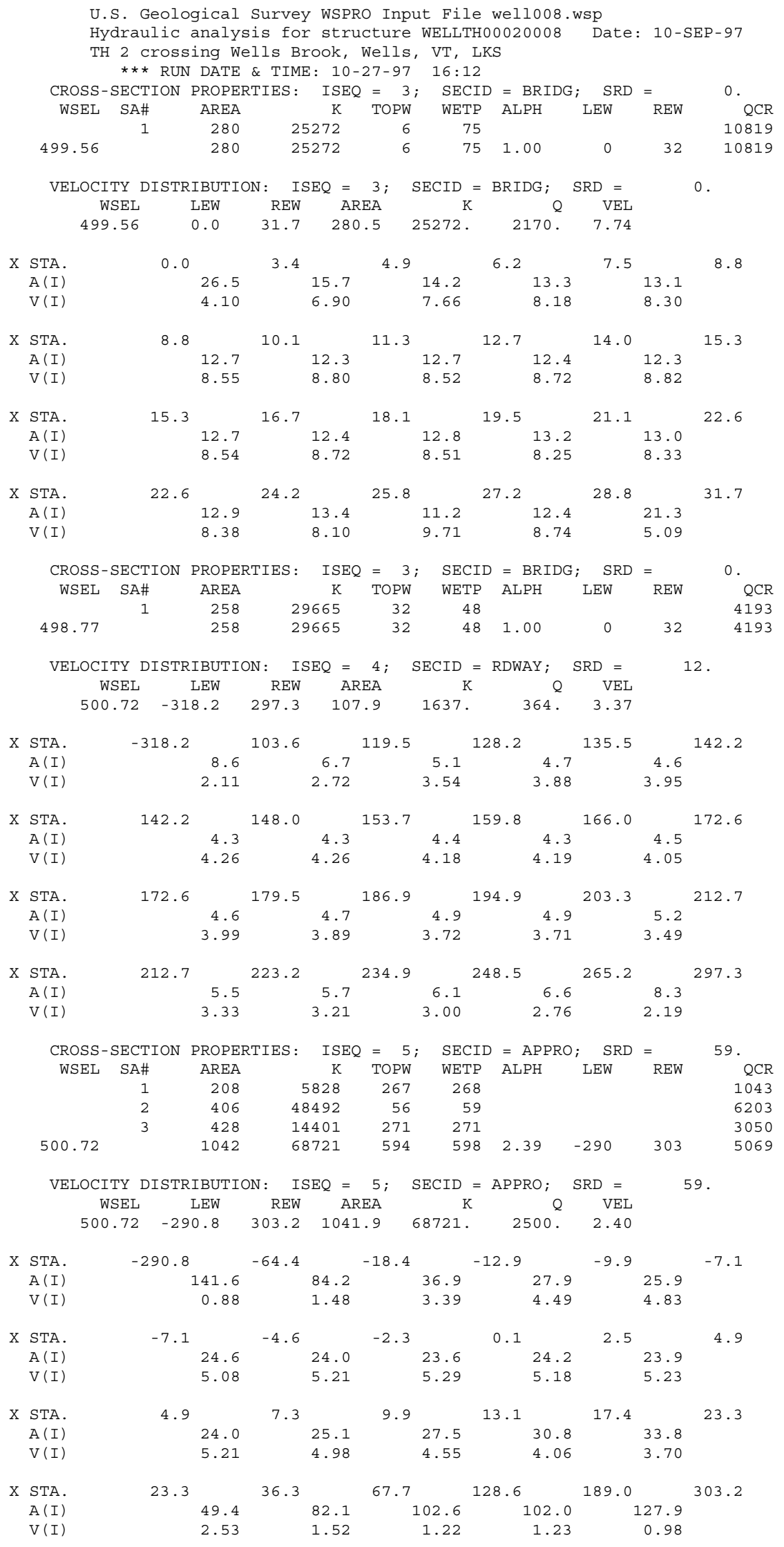


WSPRO OUTPUT FILE (continued)

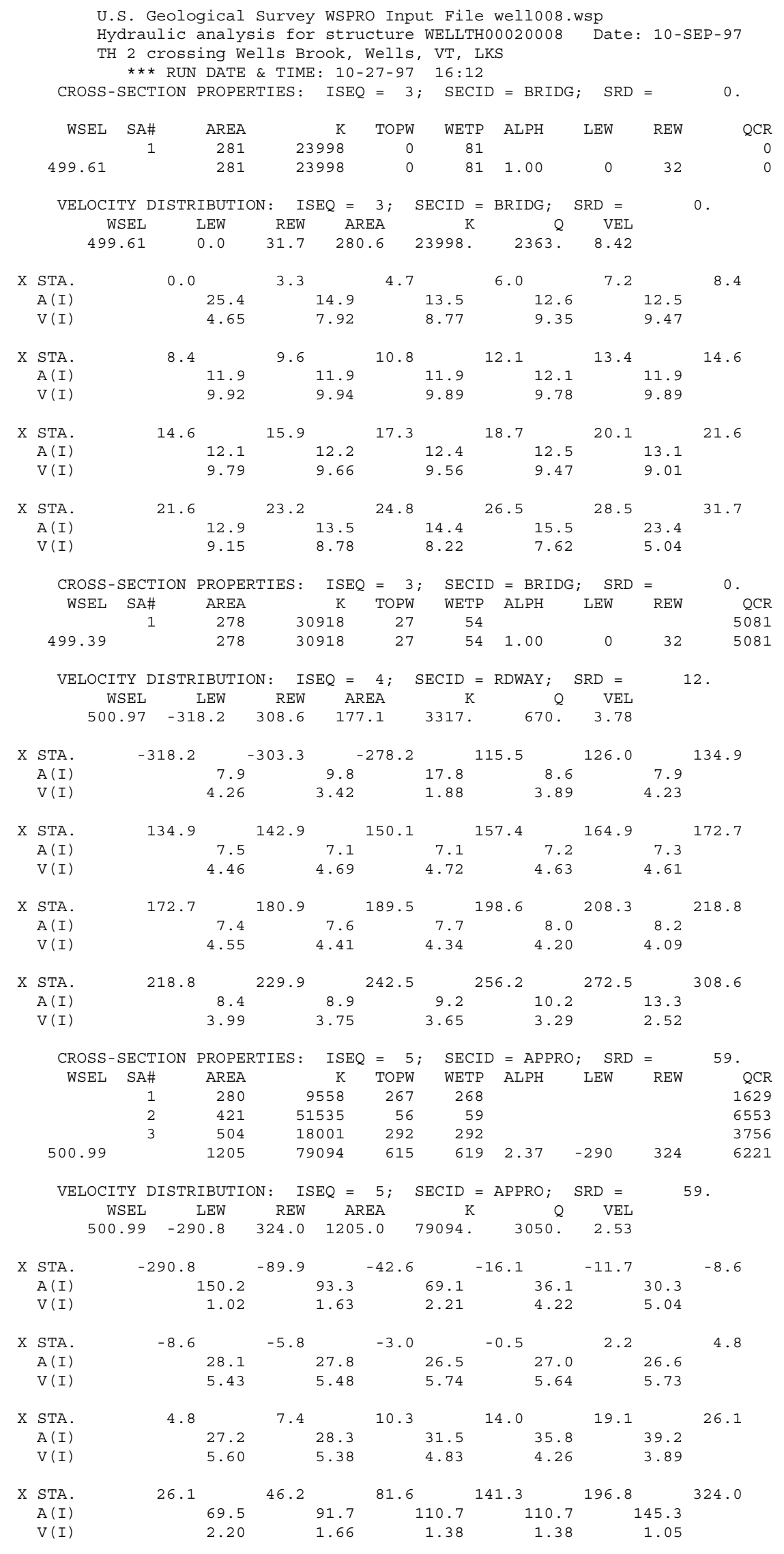


WSPRO OUTPUT FILE (continued)

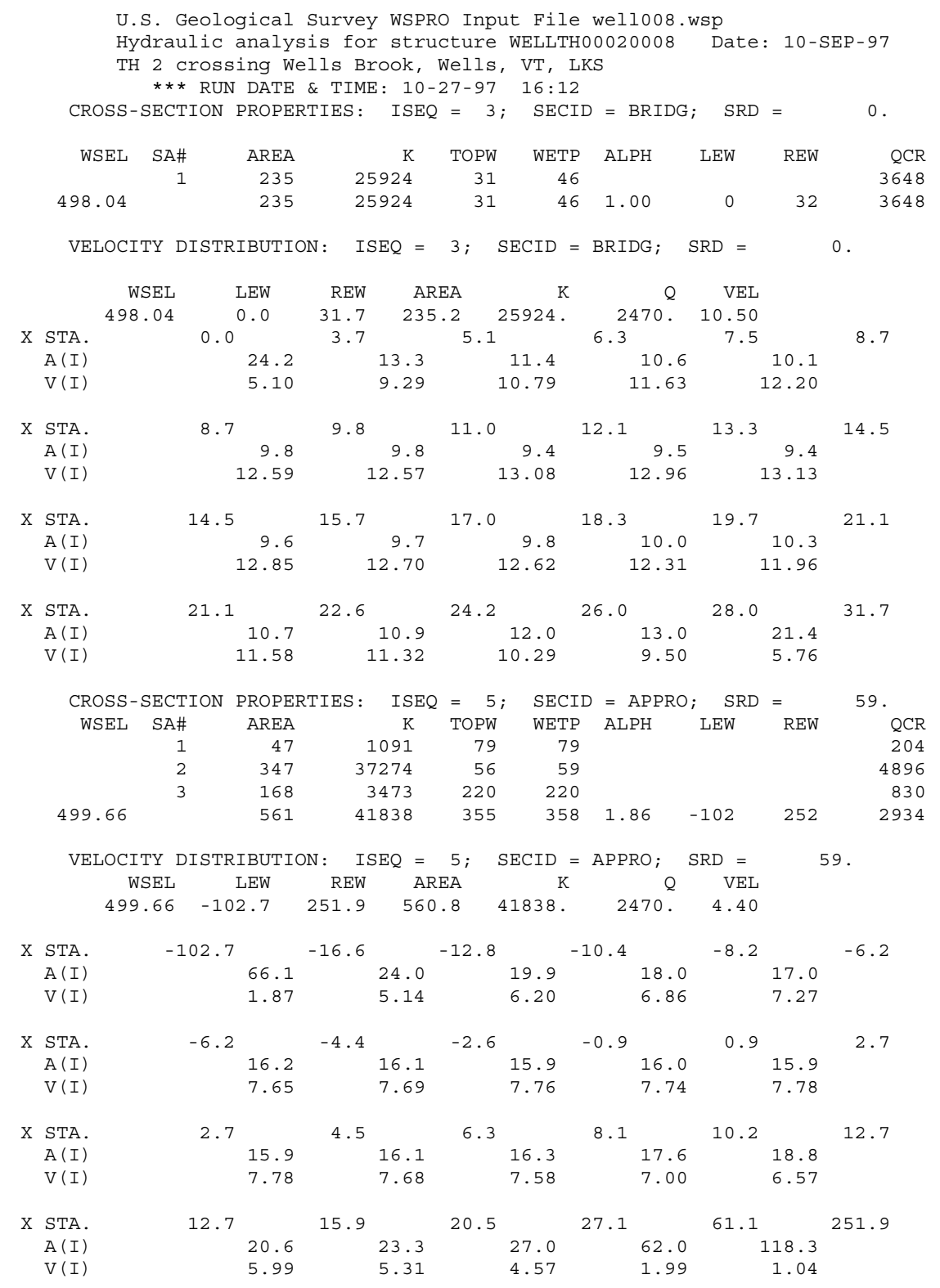


WSPRO OUTPUT FILE (continued)

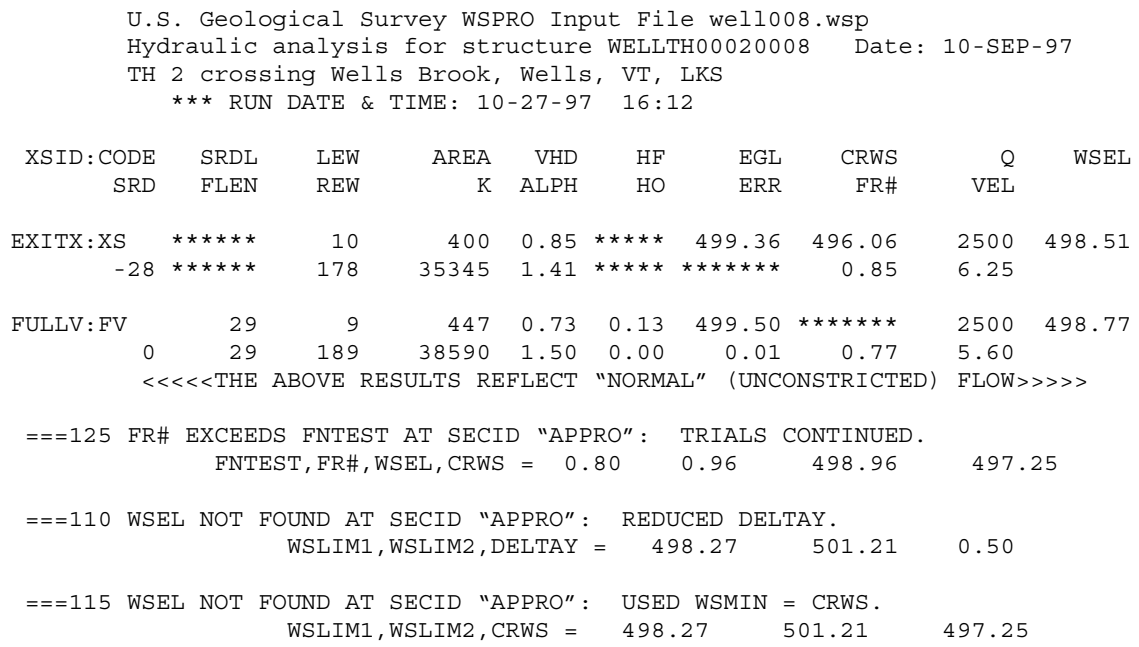

SECOND USER DEFINED TABLE.

$\begin{array}{lcrrrrrrrr}\text { XSID : CODE } & \text { CRWS } & \text { FR\# } & \text { YMIN } & \text { YMAX } & \text { HF } & \text { HO } & \text { VHD } & \text { EGL } & \text { WSEL } \\ \text { EXITX:XS } & 496.06 & 0.85 & 489.43 & 499.39 * * * * * * * * * * & 0.85 & 499.36 & 498.51 \\ \text { FULLV:FV } & * * * * * * * * & 0.77 & 489.43 & 499.39 & 0.13 & 0.00 & 0.73 & 499.50 & 498.77 \\ \text { BRIDG:BR } & 495.85 & 0.46 & 488.73 & 499.61 * * * * * * * * * * & 0.93 & 500.49 & 499.56 \\ \text { RDWAY:RG } & * * * * * * * * * * * * * * * * & 499.97 & 502.98 & 0.05 * * * * * * & 0.21 & 500.89 & 500.72 \\ \text { APPRO:AS } & 497.25 & 0.49 & 490.47 & 501.21 & 0.11 & 0.29 & 0.21 & 500.94 & 500.72\end{array}$


WSPRO OUTPUT FILE (continued)

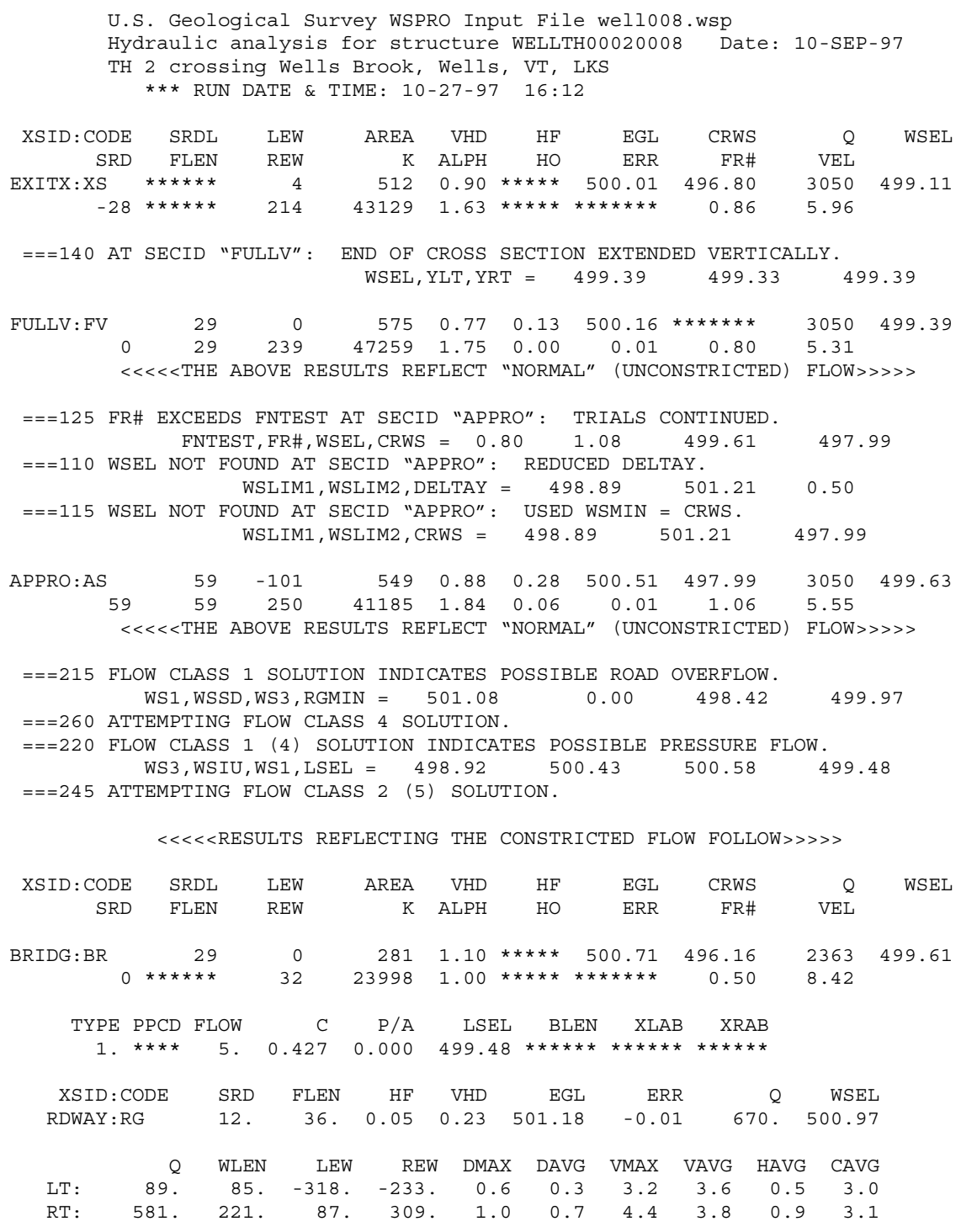

$===140 \mathrm{AT}$ SECID "APPRO": END OF CROSS SECTION EXTENDED VERTICALLY. WSEL, YLT, YRT $=500.99 \quad 500.0 \quad 501.2$

\begin{tabular}{|c|c|c|c|c|c|c|c|c|c|}
\hline XSID : CODE & SRDL & LEW & AREA & VHD & $\mathrm{HF}$ & EGL & CRWS & $\mathrm{Q}$ & WSEL \\
\hline SRD & FLEN & REW & K & ALPH & $\mathrm{HO}$ & ERR & FR\# & VEL & \\
\hline APPRO : AS & 28 & -290 & 1207 & 0.23 & 0.14 & 501.23 & 497.99 & 3050 & 500.99 \\
\hline 59 & 35 & 324 & 79247 & 2.37 & 0.24 & -0.01 & 0.49 & 2.53 & \\
\hline $\mathrm{M}(\mathrm{G})$ & $\mathrm{M}(\mathrm{K})$ & $\mathrm{KQ}$ & XLKQ & $\mathrm{XRKC}$ & & TEL & & & \\
\hline$\star \star \star \star \star \star \star *$ & $\star \star \star \star \star \star \star *$ & 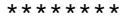 & 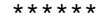 & 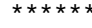 & $\star \star$ & $* * *$ & & & \\
\hline
\end{tabular}
FIRST USER DEFINED TABLE.

$<<<<$ END OF BRIDGE COMPUTATIONS $>>>>>$

\begin{tabular}{|c|c|c|c|c|c|c|c|c|}
\hline XSID : CODE & SRD & LEW & REW & $Q$ & $\mathrm{~K}$ & AREA & VEL & WSEL \\
\hline EXITX:XS & -29 & 4. & 214 . & 3050 . & 43129 . & 512. & 5.96 & 499.11 \\
\hline FULLV : FV & 0 & 0 . & 239. & 3050 . & 47259 . & 575. & 5.31 & 499.39 \\
\hline BRIDG : BR & 0 . & 0 . & 32 . & 2363 . & 23998 . & 281. & 8.42 & 499.61 \\
\hline RDWAY : RG & $12 . *$ & $* * * * *$ & 89. & 670 & $0 . *$ & $\star \star \star \star \star \star *$ & 1.00 & 500.97 \\
\hline APPRO:AS & 59. & -291. & 324. & 3050 . & 79247. & 1207. & 2.53 & 500.99 \\
\hline XSID : CODE & XLKQ & XRKQ & & & & & & \\
\hline
\end{tabular}

SECOND USER DEFINED TABLE.

$\begin{array}{lcrrrrrrrr}\text { XSID : CODE } & \text { CRWS } & \text { FR\# } & \text { YMIN } & \text { YMAX } & \text { HF } & \text { HO } & \text { VHD } & \text { EGL } & \text { WSEL } \\ \text { EXITX:XS } & 496.80 & 0.86 & 489.43 & 499.39 * * * * * * * * * * * & 0.90 & 500.01 & 499.11 \\ \text { FULLV:FV } & * * * * * * * & 0.80 & 489.43 & 499.39 & 0.13 & 0.00 & 0.77 & 500.16 & 499.39 \\ \text { BRIDG : BR } & 496.16 & 0.50 & 488.73 & 499.61 * * * * * * * * * * * & 1.10 & 500.71 & 499.61 \\ \text { RDWAY:RG } & * * * * * * * * * * * * * * & 499.97 & 502.98 & 0.05 * * * * * * & 0.23 & 501.18 & 500.97 \\ \text { APPRO:AS } & 497.99 & 0.49 & 490.47 & 501.21 & 0.14 & 0.24 & 0.23 & 501.23 & 500.99\end{array}$


WSPRO OUTPUT FILE (continued)

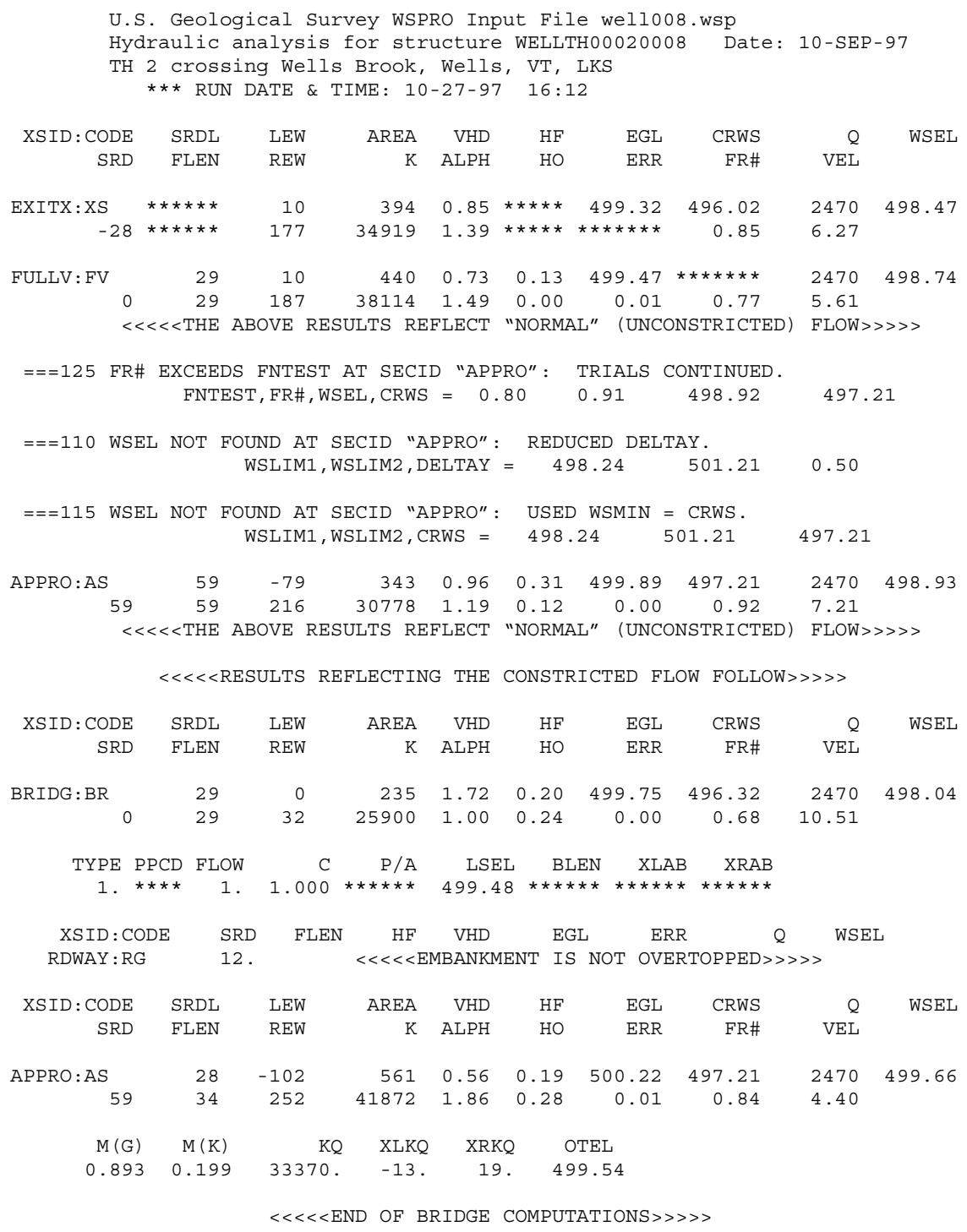

FIRST USER DEFINED TABLE.

\begin{tabular}{|c|c|c|c|c|c|c|c|c|}
\hline XSID : CODE & SRD & LEW & REW & 0 & $\mathrm{~K}$ & AREA & VEL & WSEL \\
\hline EXITX:XS & -29 & 10. & 177 . & 2470 . & 34919 . & 394. & 6.27 & 498.47 \\
\hline FULLV : FV & 0 & 10. & 187. & 2470 . & 38114 . & 440. & 5.61 & 498.74 \\
\hline BRIDG : BR & 0 . & 0 . & 32 . & 2470 . & 25900 . & 235. & 10.51 & 498.04 \\
\hline RDWAY : RG & \multicolumn{3}{|c|}{ 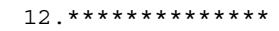 } & \multicolumn{3}{|c|}{$0 . * * * * * * * * * * * * * * * * * *$} & \multicolumn{2}{|c|}{$1.00 * * * * * * * *$} \\
\hline APPRO : AS & 59. & -103 & 252. & 2470 . & 41872 . & 561. & 4.40 & 499.66 \\
\hline XSID : CODE & XLKQ & XRKQ & & & & & & \\
\hline APPRO : AS & -13. & 19. & 33370 & & & & & \\
\hline
\end{tabular}

SECOND USER DEFINED TABLE.

\begin{tabular}{|c|c|c|c|c|c|c|c|c|c|}
\hline XSID : CODE & CRWS & FR\# & YMIN & YMAX & $\mathrm{HF}$ & $\mathrm{HO}$ & VHD & EGL & WSEL \\
\hline EXITX:XS & 496.02 & 0.85 & 489.43 & $499.39 *$ & $\star \star \star \star \star \star \star * *$ & $\star \star \star \star * *$ & 0.85 & 499.32 & 498.47 \\
\hline FULLV : FV & $\star \star \star \star \star \star \star \star \star *$ & 0.77 & 489.43 & 499.39 & 0.13 & 0.00 & 0.73 & 499.47 & 498.74 \\
\hline BRIDG : BR & 496.32 & 0.68 & 488.73 & 499.61 & 0.20 & 0.24 & 1.72 & 499.75 & 498.04 \\
\hline RDWAY : RG & 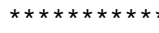 & $\star \star \star \star \star *$ & 499.97 & $502.98 *$ & 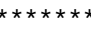 & $\star \star \star \star \star \star *$ & $\star \star \star \star \star * \star$ & 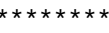 & 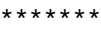 \\
\hline APPRO: AS & 497.21 & 0.84 & 490.47 & 501.21 & 0.19 & 0.28 & 0.56 & 500.22 & 499.66 \\
\hline
\end{tabular}




\section{APPENDIX C:}

\section{BED-MATERIAL PARTICLE-SIZE DISTRIBUTION}




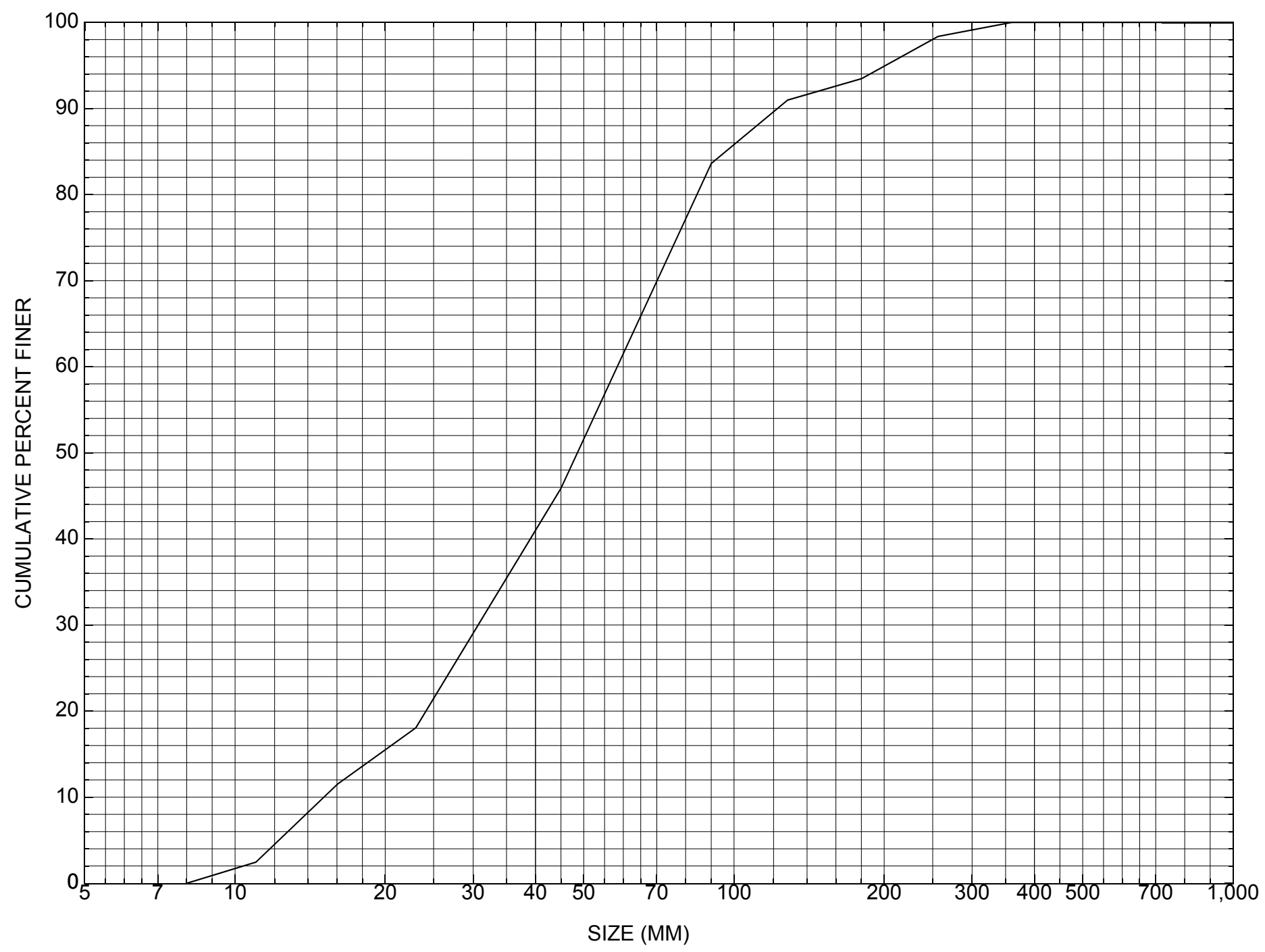

Appendix C. Bed material particle-size distribution for a pebble count in the channel approach of structure WELLTH00020008, in Wells, Vermont. 


\section{APPENDIX D: \\ HISTORICAL DATA FORM}




\section{Structure Number WELLTH00020008}

\section{General Location Descriptive}

Data collected by (First Initial, Full last name) $\mathbf{E}$. BOEHMLER

Date $(M M / D D / Y Y) \_\mathbf{0 3} / \underline{22} / \underline{95}$

Highway District Number (I - 2; nn) $\mathbf{0 3}$

Town (FIPS place code; I - 4; nnnnn) $\mathbf{7 7 9 5 0}$

Waterway (I - 6) WELLS BROOK

Route Number $\mathbf{T H 0 0 2}$

Topographic Map Wells

Latitude (I - 16; nnnn.n) $\mathbf{4 3 2 5 0}$
County (FIPS county code; I - 3; nnn)

Mile marker (I - 11; nnn.nnn) $\mathbf{0 0 0 0 0 0}$

Road Name (I - 7): -

Vicinity $(I-9) \underline{0.05}$ MI TO JCT VT 30

Hydrologic Unit Code: $\mathbf{0 2 0 1 0 0 0 1}$

Longitude (i - 17; nnnnn.n) $\mathbf{7 3 1 2 3}$

\section{Select Federal Inventory Codes}

FHWA Structure Number $(I$ - 8) 10112600081126

Maintenance responsibility $(I-21 ; n n) \quad \mathbf{0 3}$

Year built (I - 27; YYYY) 1926

Average daily traffic, ADT (I - 29; nnnnnn) 001070

Year of ADT (I - 30; YY) $\mathbf{9 2}$

Opening skew to Roadway (I - 34; nn) $\mathbf{0 5}$

Operational status $(I-41 ; X)$ A

Structure type (I - 43; nnn) 104

Approach span structure type $(I-44 ; n n n) \quad \mathbf{0 0 0}$

Number of spans (I - 45; nnn) $\underline{\mathbf{0 0 1}}$

Number of approach spans (I - 46; nnnn) $\mathbf{0 0 0 0}$

Comments:

The structural inspection report of 6/29/94 indicates the structure is a concrete T-beam type bridge with an asphalt roadway surface. The abutment walls and wingwalls are concrete. The right abutment has some spalling along its footing on the upstream end and at the upstream wingwall. The downstream wingwall has some fine, small spalls reported. The upstream left wingwall has some map cracking with signs of leaking through the cracks noted. The report indicates there is some local scour at the upstream end of the left abutment footing and its upstream wingwall footing, which extends out to about the centerline of the channel. Most of the flow is indicated as flowing against the upstream left wingwall (Continued, page 33) 


\section{Bridge Hydrologic Data}

Is there hydrologic data available? $\underline{\mathbf{N}}$ if No, type ctrl-n $h \quad$ VTAOT Drainage area $\left(m i^{2}\right)$ : -

Terrain character:

Stream character \& type: -

Streambed material:

Discharge Data (cfs):

$$
\begin{aligned}
& Q_{2.33}- \\
& Q_{50}-
\end{aligned}
$$

Record flood date $(M M / D D / Y Y)$ :

Estimated Discharge (cfs): Ice conditions (Heavy, Moderate, Light) : -

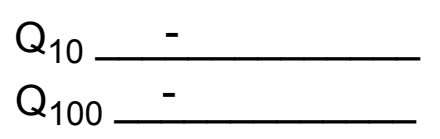

$$
\begin{aligned}
& Q_{25}- \\
& Q_{500}-
\end{aligned}
$$

Water surface elevation $(f t):-$

The stage increases to maximum highwater elevation (Rapidly, Not rapidly):

The stream response is (Flashy, Not flashy):

Describe any significant site conditions upstream or downstream that may influence the stream's stage: -

Watershed storage area (in percent): _ _ \%

The watershed storage area is: - (1-mainly at the headwaters; 2- uniformly distributed; 3-immediatly upstream oi the site)

Water Surface Elevation Estimates for Existing Structure:

\begin{tabular}{|l|l|l|l|l|l|}
\hline Peak discharge frequency & $Q_{2.33}$ & $Q_{10}$ & $Q_{25}$ & $Q_{50}$ & $Q_{100}$ \\
Water surface elevation (ft)) & - & - & - & - & - \\
Velocity (ft/sec) & - & - & - & - & - \\
\hline
\end{tabular}

Long term stream bed changes: -

Is the roadway overtopped below the $\mathrm{Q}_{100}$ ? (Yes, No, Unknown): $\mathbf{U}$ Frequency: Relief Elevation (ft): Discharge over roadway at $Q_{100}\left(f^{3} / \mathrm{sec}\right)$ :

Are there other structures nearby? (Yes, No, Unknown): $\underline{\mathbf{U}}$ Upstream distance (miles): Town: If No or Unknown, type ctrl-n os Highway No. : Structure No. : Year Built:

Clear span (ft): Clear Height $(f t)$ : Full Waterway $\left(f^{2}\right)$ : 
Downstream distance (miles): Town: Year Built:

Highway No. : Structure No. : Structure Type:

Clear span (ft): Clear Height $(f t)$ : Full Waterway $\left(f t^{2}\right)$ :

Comments:

and the upstream end of the left abutment wall. While the footings are exposed at the surface, the report indicates there has been no undermining or settling of the abutment walls or wingwalls. There is vegetation growth on the banks upstream noted in the report. The streambed consists of mainly gravel and boulders.

\section{USGS Watershed Data}

Watershed Hydrographic Data

Drainage area $(D A) \underline{14.35}$

Watershed storage (ST)

Bridge site elevation $\mathbf{5 0 1}$

Main channel length 9.069 $\mathrm{mi}^{2}$ 0 $\mathrm{ft}$ $\mathrm{mi}$
Lake/pond/swamp area $\underline{0}$

0 $\mathrm{mi}^{2}$ $\%$ $10 \%$ channel length elevation $\mathbf{5 1 8}$ $\mathrm{ft} \quad 85 \%$ channel length elevation 1779 $\mathrm{ft}$

Main channel slope $(S)$ (S) 170.691 $\mathrm{ft} / \mathrm{mi}$

Watershed Precipitation Data

Average site precipitation in Average headwater precipitation in

Maximum 2yr-24hr precipitation event $(124,2)$ in

Average seasonal snowfall (Sn) $\mathrm{ft}$ 


\section{Bridge Plan Data}

Are plans available? $\mathbf{N} \quad$ If no, type ctrl-n pl Date issued for construction (MM / YYYY):

Project Number

Minimum channel bed elevation:

Low superstructure elevation: USLAB DSLAB USRAB DSRAB Benchmark location description:

There is no benchmark information available.

Reference Point (MSL, Arbitrary, Other): Datum (NAD27, NAD83, Other):

Foundation Type: 4

If 1: Footing Thickness

If 2: Pile Type: (1-Wood; 2-S

(1-

(1-Spreadfooting; 2-Pile; 3- Gravity; 4-Unknown)

Footing bottom elevation:

If 3 : Footing bottom elevation:
Is boring information available?

Foundation Material Type: 3

Briefly describe material at foundation bottom elevation or around piles:

There is no foundation material information available.

Comments:

There are no bridge plans available. 


\section{Cross-sectional Data}

Is cross-sectional data available? Yes If no, type ctrl-n xs

Source (FEMA, VTAOT, Other)? VTAOT

Comments: The low chord to bed, and station distances of this cross section are taken from a sketch dated $12 / 02 / 92$ that is attached to a bridge inspection report. The low chord elevations were taken from the 09/19/95 survey done for this report.

\begin{tabular}{|l|l|l|l|l|l|l|l|l|l|l|l|}
\hline Station & $\mathbf{0}$ & $\mathbf{2 . 0 8}$ & $\mathbf{2 . 0 9}$ & $\mathbf{1 0 . 0 8}$ & $\mathbf{2 9 . 7 5}$ & - & - & - & - & - & - \\
\hline Feature & LAB & - & - & - & RAB & - & - & - & - & - & - \\
\hline $\begin{array}{l}\text { Low chord } \\
\text { elevation }\end{array}$ & 499.36 & $\mathbf{4 9 9 . 3 8}$ & $\mathbf{4 9 9 . 3 8}$ & $\mathbf{4 9 9 . 4 4}$ & $\mathbf{4 9 9 . 6 1}$ & - & - & - & - & - & - \\
\hline $\begin{array}{l}\text { Bed } \\
\text { elevation }\end{array}$ & 492.78 & $\mathbf{4 9 2 . 8 0}$ & $\mathbf{4 8 8 . 3 8}$ & $\mathbf{4 8 9 . 9 4}$ & $\mathbf{4 9 2 . 4 4}$ & - & - & - & - & - & - \\
\hline $\begin{array}{l}\text { Low chord } \\
\text { to bed }\end{array}$ & $\mathbf{6 . 5 8}$ & $\mathbf{6 . 5 8}$ & $\mathbf{1 1 . 0 0}$ & $\mathbf{9 . 5 0}$ & 7.17 & - & - & - & - & - & - \\
\hline Station & - & - & - & - & - & - & - & - & - & - & - \\
\hline Feature & - & - & - & - & - & - & - & - & - & - & - \\
\hline $\begin{array}{l}\text { Low chord } \\
\text { elevation }\end{array}$ & - & - & - & - & - & - & - & - & - & - & - \\
\hline $\begin{array}{l}\text { Bed } \\
\text { elevation }\end{array}$ & - & - & - & - & - & - & - & - & - & - & - \\
\hline $\begin{array}{l}\text { Low chord } \\
\text { to bed }\end{array}$ & - & - & - & - & - & - & - & - & - & - & - \\
\hline
\end{tabular}

Source (FEMA, VTAOT, Other)?

Comments: -

\begin{tabular}{|l|l|l|l|l|l|l|l|l|l|l|l|}
\hline Station & - & - & - & - & - & - & - & - & - & - & - \\
\hline Feature & - & - & - & - & - & - & - & - & - & - & - \\
\hline $\begin{array}{l}\text { Low chord } \\
\text { elevation }\end{array}$ & - & - & - & - & - & - & - & - & - & - & - \\
\hline $\begin{array}{l}\text { Bed } \\
\text { elevation }\end{array}$ & - & - & - & - & & - & - & - & - & - & - \\
\hline $\begin{array}{l}\text { Low chord } \\
\text { to bed }\end{array}$ & - & - & - & - & - & - & - & - & - & - & - \\
\hline Station & - & - & - & - & - & - & - & - & - & - & - \\
\hline Feature & - & - & - & - & - & - & - & - & - & - & - \\
\hline $\begin{array}{l}\text { Low chord } \\
\text { elevation }\end{array}$ & - & - & - & - & - & - & - & - & - & - & - \\
\hline $\begin{array}{l}\text { Bed } \\
\text { elevation }\end{array}$ & - & - & - & - & - & - & - & - & - & - & - \\
\hline $\begin{array}{l}\text { Low chord } \\
\text { to bed }\end{array}$ & - & - & - & - & - & - & - & - & - & - & - \\
\hline
\end{tabular}




\section{APPENDIX E: \\ LEVEL I DATA FORM}


U. S. Geological Survey

Bridge Field Data Collection and Processing Form

Qa/Qc Check by: RB Date: $2 / 21 / 96$

Computerized by: $\mathbf{R B}$ Date: $2 / 21 / 96$

\section{Structure Number WELLTH00020008}

Reviewd by: LKS Date: 10/27/97

\section{A. General Location Descriptive}

1. Data collected by (First Initial, Full last name) M. IVANOFF

Date $(M M / D D / Y Y)$

9

2. Highway District Number $\mathbf{3}$

Mile marker $\mathbf{0}$

County Rutland (021)

Town Wells (77950)

Waterway (I - 6) Wells Brook

Road Name -

Route Number $\mathbf{T H 2}$

Hydrologic Unit Code: $\mathbf{0 2 0 1 0 0 0 1}$

3. Descriptive comments:

The bridge is located 0.05 miles from the junction with VT 30.

\section{B. Bridge Deck Observations}
4. Surface cover... LBUS 4
RBUS 2
LBDS 4
RBDS 2
Overall 2

(2b us,ds,lb,rb: 1- Urban; 2- Suburban; 3- Row crops; 4- Pasture; 5- Shrub- and brushland; 6- Forest; 7- Wetland)
5. Ambient water surface... US 2
UB 1
DS $\underline{2}$
(1- pool; 2- riffle)

6. Bridge structure type 1 (1- single span; 2- multiple span; 3- single arch; 4- multiple arch; 5-cylindrical culvert; 6- box culvert; or 7- other)
7. Bridge length $\mathbf{3 5}$
(feet)
Span length $\underline{\mathbf{3 2}}$
(feet)
Bridge width $\underline{\mathbf{2 3 . 3}}$ (feet)

\section{Road approach to bridge:}
8. LB 1 RB 1
( 0 even, 1- lower, 2- higher)
9. $\mathrm{LB}$ RB 1
(1-Paved, 2- Not paved)

10. Embankment slope (run / rise in feet / foot):

US left

US right

\begin{tabular}{|c|c|c|c|c|}
\hline & \multicolumn{2}{|c|}{ Protection } & \multirow{2}{*}{ 13.Erosion } & \multirow{2}{*}{ 14.Severity } \\
\hline & 11.Type & 12. Cond. & & \\
\hline LBUS & $\mathbf{0}$ & - & $\mathbf{0}$ & $\mathbf{0}$ \\
\hline RBUS & $\mathbf{0}$ & - & $\mathbf{0}$ & $\mathbf{0}$ \\
\hline RBDS & 5 & 1 & $\mathbf{0}$ & $\mathbf{0}$ \\
\hline LBDS & $\mathbf{0}$ & - & $\mathbf{0}$ & $\mathbf{0}$ \\
\hline
\end{tabular}

Bank protection types: 0- none; 1- < 12 inches;

2- < 36 inches; $3-<48$ inches;

4- $<60$ inches; 5- wall / artificial levee

Bank protection conditions: 1- good; 2- slumped;

3- eroded; 4- failed

Erosion: 0 - none; 1- channel erosion; 2-

road wash; 3- both; 4- other

Erosion Severity: 0 - none; 1- slight; 2- moderate;

\section{Channel approach to bridge (BF):}

15. Angle of approach: $\mathbf{0}$

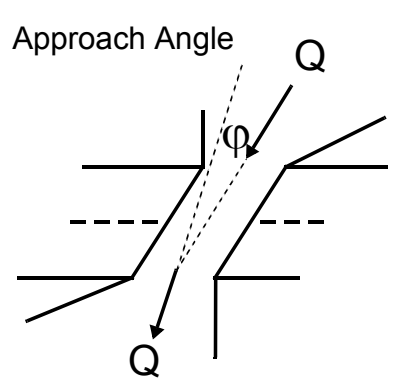

17. Channel impact zone 1 :

Where? LB (LB, RB)

Range? 13

Channel impact zone 2:

Where? RB (LB, RB)

Range? $\underline{\mathbf{8}}$ feet $\underline{\mathbf{U B}}$ (US, UB, DS) to $\underline{\mathbf{0}}$ feet $\underline{\mathbf{D S}}$

Impact Severity: 0- none to very slight; 1- Slight; 2- Moderate; 3- Severe
16. Bridge skew: 10 Bridge Skew Angle

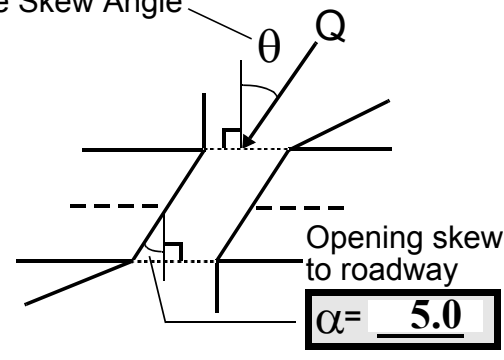

\section{Exist? $\underline{\mathbf{Y}}(\mathrm{Y}$ or $N)$}

Severity 1

S, UB, DS) to $\underline{\mathbf{0}}$ feet $\underline{\mathbf{U S}}$

Exist? $\mathbf{Y}(Y$ or $N)$

Severity 1 
18. Bridge Type: $1 \mathbf{1 a} / 4$

1a- Vertical abutments with wingwalls

1 b- Vertical abutments without wingwalls

2- Vertical abutments and wingwalls, sloping embankment

Wingwalls parallel to abut. face

3- Spill through abutments

4- Sloping embankment, vertical wingwalls and abutments

Wingwall angle less than $90^{\circ}$.

1 a with wingwalls

19. Bridge Deck Comments (surface cover variations, measured bridge and span lengths, bridge type variations, approach overflow width, etc.)

\section{Bridge measurement values given are from VT AOT files.}

\section{Upstream Channel Assessment}

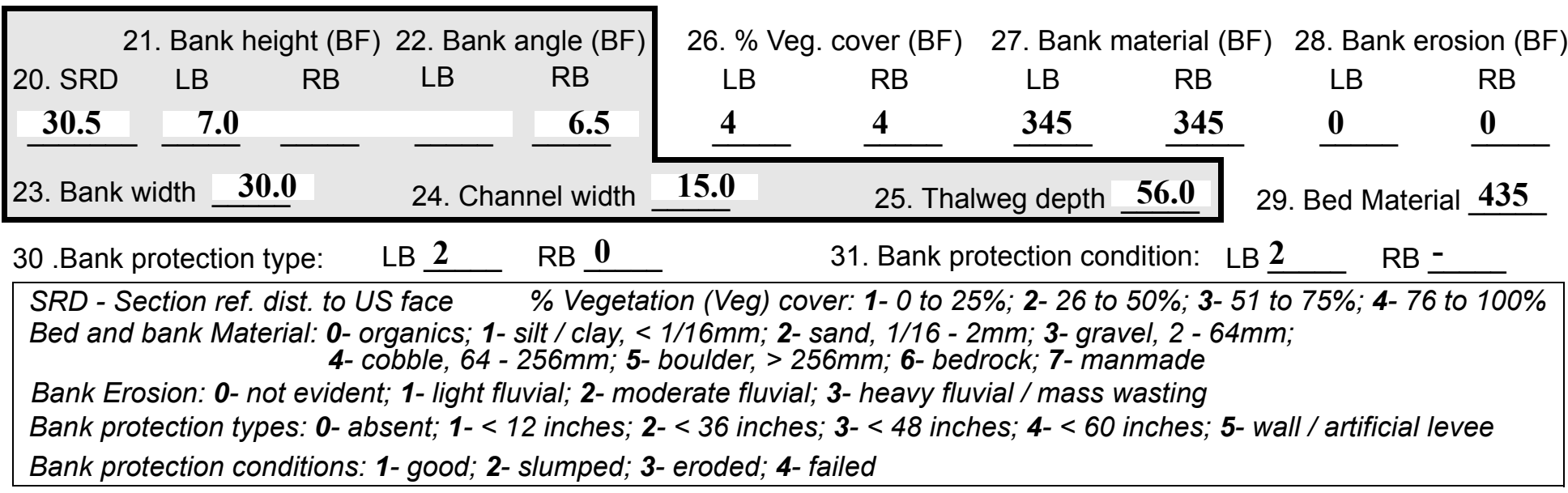

32. Comments (bank material variation, minor inflows, protection extent, etc.):

30. The left bank protection extends 7 feet from the end of the wingwall. 
33.Point/Side bar present? $\mathbf{N}(Y$ or $N$. if $N$ type ctrl-n pb)34. Mid-bar distance: -

35. Mid-bar width:

36. Point bar extent: feet (US, UB) to feet (US, UB, DS) positioned $\%$ LB to $\% \mathrm{RB}$

37. Material: -

38. Point or side bar comments (Circle Point or Side; Note additional bars, material variation, status, etc.):

There are no point bars upstream at this site.

39. Is a cut-bank present? $\underline{\mathbf{N}}$ (Y or if $\mathrm{N}$ type ctrl-n cb)

40. Where? (LB or $R B)$

41. Mid-bank distance: -

42. Cut bank extent: feet (US, UB) to feet (US, UB, DS)

43. Bank damage: ( 1- eroded and/or creep; 2- slip failure; 3- block failure)

44. Cut bank comments (eg. additional cut banks, protection condition, etc.):

There are no cut-banks upstream at this site.

\section{Is channel scour present? $\mathbf{N}$ ( $Y$ or if $N$ type ctrl-n cs)}

47. Scour dimensions: Length Width Depth : 46. Mid-scour distance: -

48. Scour comments (eg. additional scour areas, local scouring process, etc.):

There is no channel scour upstream at this site.

\section{Are there major confluences? $\mathbf{N}$}

51. Confluence 1: Distance Confluence 2: Distance 52. Enters on Enters on ( $L B$ or $R B)$ (LB or $R B)$

54. Confluence comments (eg. confluence name):

There are no major confluences upstream at this site.

\section{Under Bridge Channel Assessment}

55. Channel restraint (BF)? LB 2 (1- natural bank; 2- abutment; 3- artificial levee)

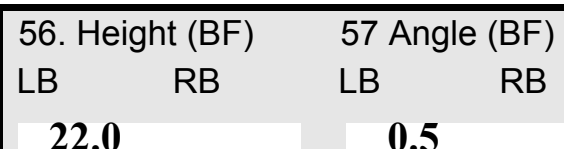

58. Bank width (BF) ...

61. Material (BF)

LB RB

$2 \quad 7$
62. Erosion (BF)

LB RB

7

53. Type(1- perennial; 2- ephemeral)

Type (1- perennial; 2- ephemeral)

Bed and bank Material: 0- organics; 1- silt / clay, < 1/16mm; 2- sand, 1/16 - 2mm; 3- gravel, 2 - 64mm; 4- cobble, 64 - 256mm; 5- boulder, > 256mm; 6- bedrock; 7- manmade

Bank Erosion: 0- not evident; 1- light fluvial; 2- moderate fluvial; 3- heavy fluvial / mass wasting

64. Comments (bank material variation, minor inflows, protection extent, etc.):

34 
65. Debris and Ice Is there debris accumulation?

$(Y$ or $N)$ 66. Where? $\mathbf{N}$

(1- Upstream; 2- At bridge; 3- Both)

67. Debris Potential ( 1- Low; 2- Moderate; 3- High)

68. Capture Efficiency 2 (1-Low; 2- Moderate; 3- High)

69. Is there evidence of ice build-up? 1 (Y or $N)$

Ice Blockage Potential $\mathbf{N}$

(1- Low; 2- Moderate; 3- High)

70. Debris and Ice Comments:

1

There are many trees along the US banks that pose a threat for potential debris problems.

\begin{tabular}{|l|c|c|c|c|c|c|c|c|}
\hline Abutments & $\begin{array}{c}\text { 71. Attack } \\
\angle \text { (BF) }\end{array}$ & $\begin{array}{c}\text { 72. Slope } \angle \\
\text { (Qmax) }\end{array}$ & $\begin{array}{c}\text { 73. Toe } \\
\text { loc. (BF) }\end{array}$ & $\begin{array}{c}\text { 74. Scour } \\
\text { Condition }\end{array}$ & $\begin{array}{c}75 . \text { Scour } \\
\text { depth }\end{array}$ & $\begin{array}{c}\text { 76. Exposure } \\
\text { depth }\end{array}$ & 77. Material & 78. Length \\
\hline LABUT & & $\mathbf{0}$ & $\mathbf{9 0}$ & $\mathbf{2}$ & $\mathbf{2}$ & $\mathbf{1 . 5}$ & $\mathbf{4}$ & $\mathbf{9 0 . 0}$ \\
\hline RABUT & $\mathbf{1}$ & $\mathbf{5}$ & $\mathbf{9 0}$ & & & $\mathbf{2}$ & $\mathbf{2}$ & $\mathbf{3 1 . 5}$ \\
\hline
\end{tabular}

Pushed: $L B$ or RB

Toe Location (Loc.): 0- even, 1- set back, 2- protrudes

Scour cond.: 0- not evident; 1- evident (comment); 2- footing exposed; 3-undermined footing; 4- piling exposed; 5- settled; 6- failed

Materials: 1- Concrete; 2- Stone masonry or drywall; 3- steel or metal; 4- wood

79. Abutment comments (eg. undermined penetration, unusual scour processes, debris, etc.):

0

2.2

1

The stream is impacting the US left wingwall and abutment.

74. Maximum exposure and scour is at the US end of the left abutment and DS end of the right abutment.

The scour extends for 12 feet along the left abutment and for 10 feet along the DS end of the right abutment.

The left abutment footing has 1964 engraved on the DS end.

80. Wingwalls:

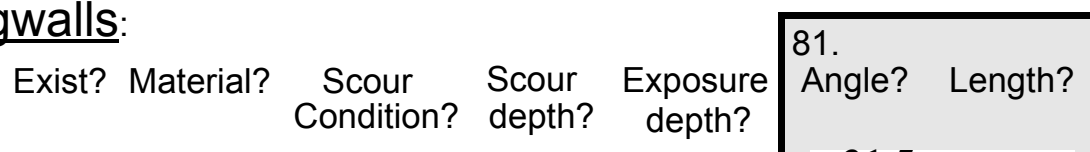

USLWW:

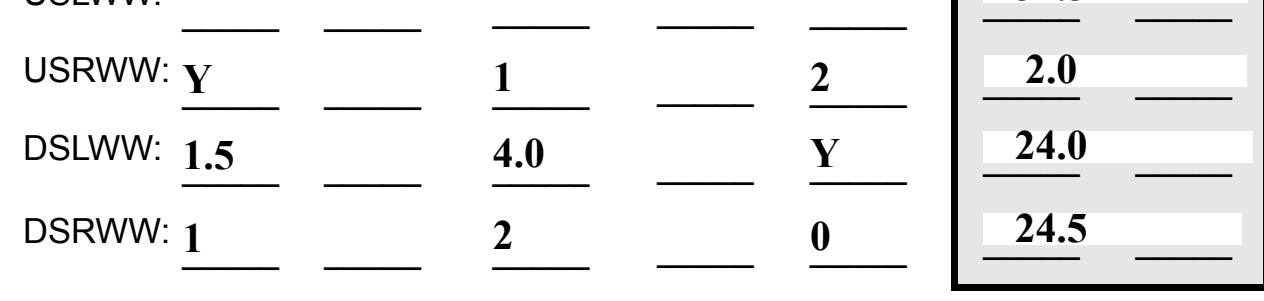

Wingwall materials: 1- Concrete; 2- Stone masonry or drywall; 3- steel or metal; 4- wood

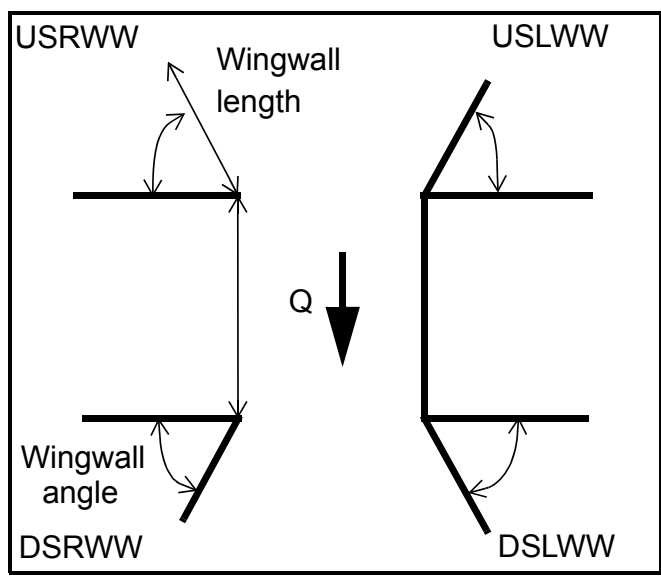

82. Bank / Bridge Protection:

\begin{tabular}{|l|l|l|l|l|l|l|c|c|}
\hline Location & USLWW & USRWW & LABUT & RABUT & LB & RB & DSLWW & DSRWW \\
\hline Type & $\mathbf{2}$ & $\mathbf{0}$ & $\mathbf{Y}$ & $\mathbf{. 2}$ & $\mathbf{2}$ & - & - & - \\
\hline Condition & $\mathbf{Y}$ & - & $\mathbf{1}$ & $\mathbf{2}$ & $\mathbf{2}$ & - & - & - \\
\hline Extent & $\mathbf{1}$ & - & $\mathbf{3}$ & $\mathbf{5}$ & $\mathbf{0}$ & $\mathbf{0}$ & $\mathbf{0}$ & - \\
\hline
\end{tabular}

Bank / Bridge protection types: 0- absent; 1- < 12 inches; 2- < 36 inches; 3- < 48 inches; 4- < 60 inches; 
83. Wingwall and protection comments (eg. undermined penetration, unusual scour processes, etc.):

-
-
-
-
-
5
1
3
0
-
-

\section{Piers:}

84. Are there piers? 80. (Y or if $N$ type ctrl-n pr)

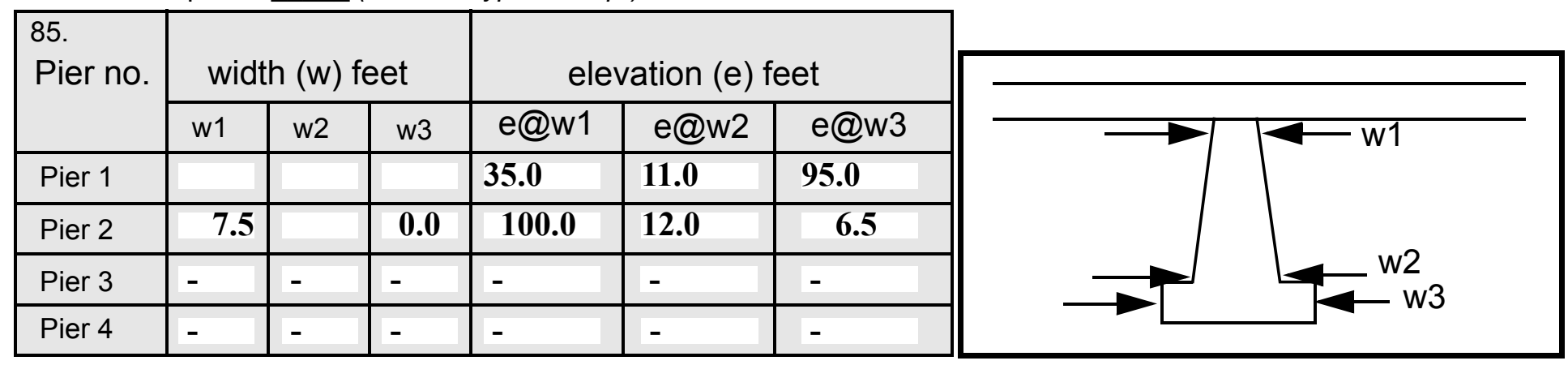

\begin{tabular}{|l|l|l|l|l|}
\hline Level 1 Pier Descr. & \multicolumn{1}{|c|}{1} & \multicolumn{1}{|c|}{2} & \multicolumn{1}{|c|}{3} & \multicolumn{1}{|c|}{4} \\
\hline 86. Location (BF) & The & flow & tion & is \\
\hline 87. Type & US & with & with & unde \\
\hline 88. Material & left & the & the & rmin \\
\hline 89. Shape & wing & max- & abut & ed \\
\hline 90. Inclined? & wall & imu & ment & 0.2 ft \\
\hline 91. Attack $\angle$ (BF) & is & m & .The & at \\
\hline 92. Pushed & impa & scou & DS & end \\
\hline 93. Length (feet) & - & - & - & - \\
\hline 94. \# of piles & cted & r at & right & of \\
\hline 95. Cross-members & by & the & wing & abut \\
\hline 96. Scour Condition & the & cor- & wall & ment \\
\hline 97. Scour depth & strea & ner & cor- & foot- \\
\hline 98. Exposure depth & m & junc- & ner & ing. \\
\hline
\end{tabular}

LFP, LTB, LB, MCL, MCM, MCR, RB, RTB, RFP

1- Solid pier, 2- column, 3- bent

1-Wood; 2- concrete; 3- metal; 4- stone

1- Round; 2- Square; 3- Pointed

Y-yes; $N-$ no

$L B$ or $R B$

0- none; 1- laterals; 2- diagonals; 3- both

0- not evident; 1- evident (comment);

2- footing exposed; 3- piling exposed;

4- undermined footing; 5- settled; 6- failed 
99. Pier comments (eg. undermined penetration, protection and protection extent, unusual scour processes, etc.):

\section{The US left wingwall protection consists of a laid-up stone wall extending $7 \mathrm{ft}$ US.}

The DS left wingwall protection consists of a laid-up stone wall extending from the end of the wingwall to $70 \mathrm{ft}$ DS of the bridge.

$\mathbf{N}$

100.

\section{E. Downstream Channel Assessment}

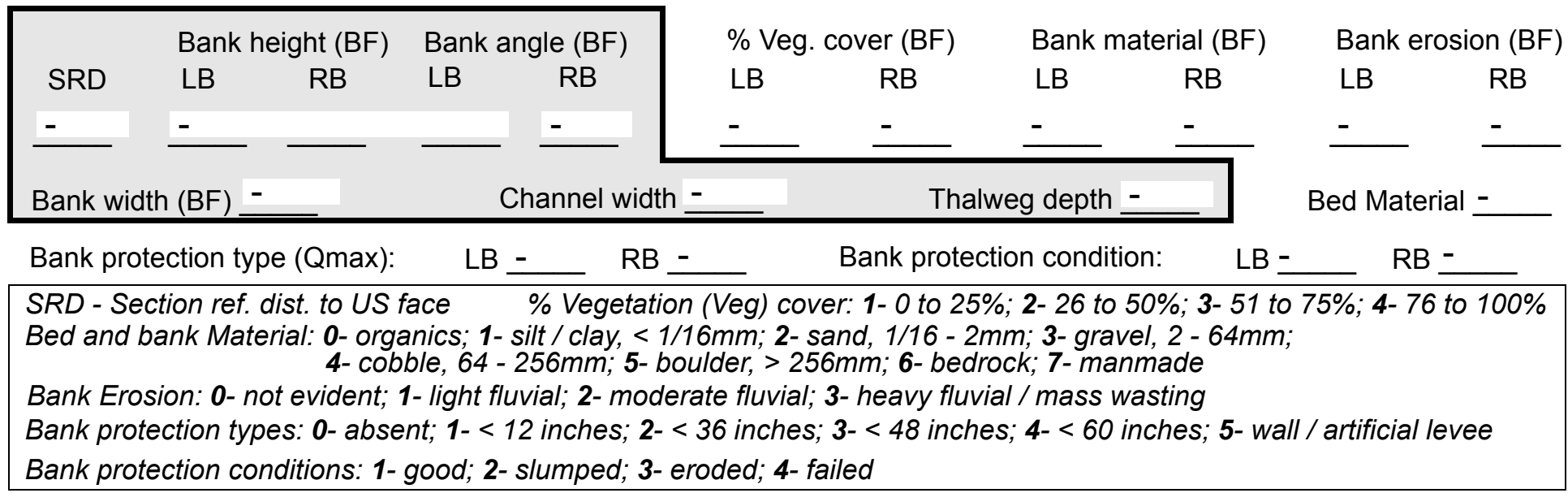

Comments (eg. bank material variation, minor inflows, protection extent, etc.):

$-$

$-$

-

-

-

-

-

-

-

-

$-$

-

$-$

\section{Is a drop structure present? __ ( $Y$ or $N$, if $N$ type ctrl-n $d s) \quad$ 102. Distance: ___ feet}
103. Drop: - feet
104. Structure material:
(1- steel sheet pile; 2- wood pile; 3- concrete; 4- other)

105. Drop structure comments (eg. downstream scour depth):

-

$-$

-

- 
106. Point/Side bar present? (Y or $N$. if $N$ type ctrl-n pb)Mid-bar distance:

Mid-bar width: -

Point bar extent: feet -

(US, UB, DS) to feet (US, UB, DS) positioned \%LB to $\% \mathrm{RB}$

Material:

Point or side bar comments (Circle Point or Side; yote additional bars, material variation, status, etc.):

S a cut-bank present? Th ( $Y$ or if $N$ type ctrl-n cb) Where? ere (LB or RB) Mid-bank distance: are Cut bank extent: no feet pie (US, UB, DS) to rs. feet ___ (US, UB, DS)

Bank damage: (1- eroded and/or creep; 2- slip failure; 3- block failure)

Cut bank comments (eg. additional cut banks, protection condition, etc.):

Is channel scour present? ( $Y$ or if $N$ type ctrl-n cs)

Mid-scour distance:

Scour dimensions: Length Width 2 Depth: 3

Positioned $\underline{\mathbf{3 4}} \% \mathrm{LB}$ to $\underline{\mathbf{3 4}} \% \mathrm{RB}$

Scour comments (eg. additional scour areas, local scouring process, etc.): $\mathbf{0}$ 1 435

5

Are there major confluences? $\mathbf{0}$ ( $Y$ or if $N$ type ctrl-n $m c$ ) How many? 1

Confluence 1: Distance Enters on The ( $L B$ or RB)

Type left (1- perennial; 2- ephemeral)

Confluence 2: Distance bank Enters on $\underline{\text { is }}$ (LB or $R B)$

Type pro- (1- perennial; 2- ephemeral) Confluence comments (eg. confluence name):

tected by a laid-up stone wall beginning at the end of the concrete wingwall and extending $70 \mathrm{ft}$ DS.

\section{F. Geomorphic Channel Assessment}

107. Stage of reach evolution

1- Constructed

2- Stable

3- Aggraded

4- Degraded

5- Laterally unstable

6- Vertically and laterally unstable 
108. Evolution comments (Channel evolution not considering bridge effects; See HEC-20, Figure 1 for geomorphic descriptors): 


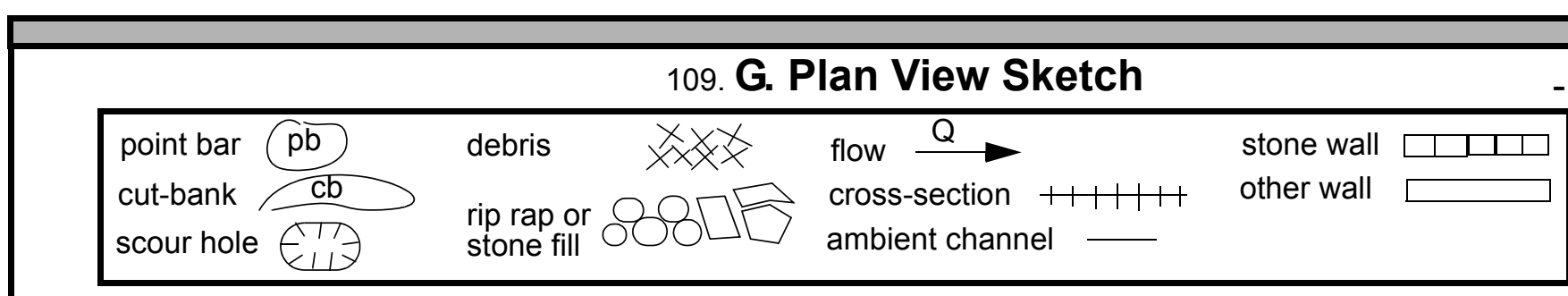

cut-bank $\mathrm{cb}$

scour hole rip rap or
stone fill stone fill cross-section $+1+1+1$ ambient channe other wall 
APPENDIX F:

SCOUR COMPUTATIONS 
SCOUR COMPUTATIONS

\begin{tabular}{|c|c|c|c|}
\hline Structure Number: WELLTH00020008 & & Town: & WELLS \\
\hline Road Number: $\quad$ TOWN HIGHWAY 2 & & County: & RUTLAND \\
\hline WELLS BROOK & & & \\
\hline Initials LKS & Checked: & SAO & \\
\hline Analysis of contraction scour, live & -bed or $\mathrm{c}$ & lear wate & \\
\hline $\begin{array}{l}\text { Critical Velocity of Bed Material } \\
\mathrm{VC}=11.21 * \mathrm{Y} 1^{\wedge} 0.1667 * \mathrm{D} 50^{\wedge} 0.33 \text { with Ss}\end{array}$ & $\begin{array}{l}\text { converted } \\
=2.65\end{array}$ & to Engl: & sh units) \\
\hline (Richardson and others, 1995, p. 28 & , eq. 16) & & \\
\hline Approach Section & & & \\
\hline Characteristic & $100 \mathrm{yr}$ & $500 \mathrm{yr}$ & other $Q$ \\
\hline Total discharge, cfs & 2500 & 3050 & 2470 \\
\hline Main Channel Area, ft2 & 406 & 421 & 347 \\
\hline Left overbank area, ft2 & 208 & 280 & 47 \\
\hline Right overbank area, ft2 & 428 & 504 & 168 \\
\hline Top width main channel, ft & 56 & 56 & 56 \\
\hline Top width L overbank, ft & 267 & 267 & 79 \\
\hline Top width $\mathrm{R}$ overbank, ft & 271 & 292 & 220 \\
\hline D50 of channel, ft & 0.1594 & 0.1594 & 0.1594 \\
\hline D50 left overbank, ft & -- & -- & -- \\
\hline D50 right overbank, ft & -- & -- & -- \\
\hline Y1, average depth, MC, ft & 7.3 & 7.5 & 6.2 \\
\hline Y1, average depth, LOB, ft & 0.8 & 1.0 & 0.6 \\
\hline $\mathrm{Y}_{1}$, average depth, ROB, ft & 1.6 & 1.7 & 0.8 \\
\hline Total conveyance, approach & 68721 & 79094 & 41838 \\
\hline Conveyance, main channel & 48492 & 51535 & 37274 \\
\hline Conveyance, LOB & 5828 & 9558 & 1091 \\
\hline Conveyance, ROB & 14401 & 18001 & 3473 \\
\hline Percent discrepancy, conveyance & 0.0000 & 0.0000 & 0.0000 \\
\hline Qm, discharge, MC, cfs & 1764.1 & 1987.3 & 2200.6 \\
\hline Q1, discharge, LOB, cfs & 212.0 & 368.6 & 64.4 \\
\hline Qr, discharge, ROB, cfs & 523.9 & 694.1 & 205.0 \\
\hline Vm, mean velocity $\mathrm{MC}$, ft/s & 4.3 & 4.7 & 6.3 \\
\hline V1, mean velocity, LOB, ft/s & 1.0 & 1.3 & 1.4 \\
\hline Vr, mean velocity, $\mathrm{ROB}$, ft/s & 1.2 & 1.4 & 1.2 \\
\hline Vc-m, crit. velocity, $\mathrm{MC}$, ft/s & 8.5 & 8.5 & 8.2 \\
\hline Vc-l, crit. velocity, LOB, ft/s & ERR & ERR & ERR \\
\hline Vc-r, crit. velocity, ROB, ft/s & $\mathrm{ERR}$ & ERR & ERR \\
\hline Results & & & \\
\hline Live-bed(1) or Clear-Water(0) Contr & action $\mathrm{Sc}$ & our? & \\
\hline Main Channel & 0 & 0 & 0 \\
\hline Left Overbank & $\mathrm{N} / \mathrm{A}$ & $\mathrm{N} / \mathrm{A}$ & $\mathrm{N} / \mathrm{A}$ \\
\hline Right Overbank & $\mathrm{N} / \mathrm{A}$ & $\mathrm{N} / \mathrm{A}$ & $\mathrm{N} / \mathrm{A}$ \\
\hline
\end{tabular}




\section{Clear Water Contraction Scour in MAIN CHANNEL}

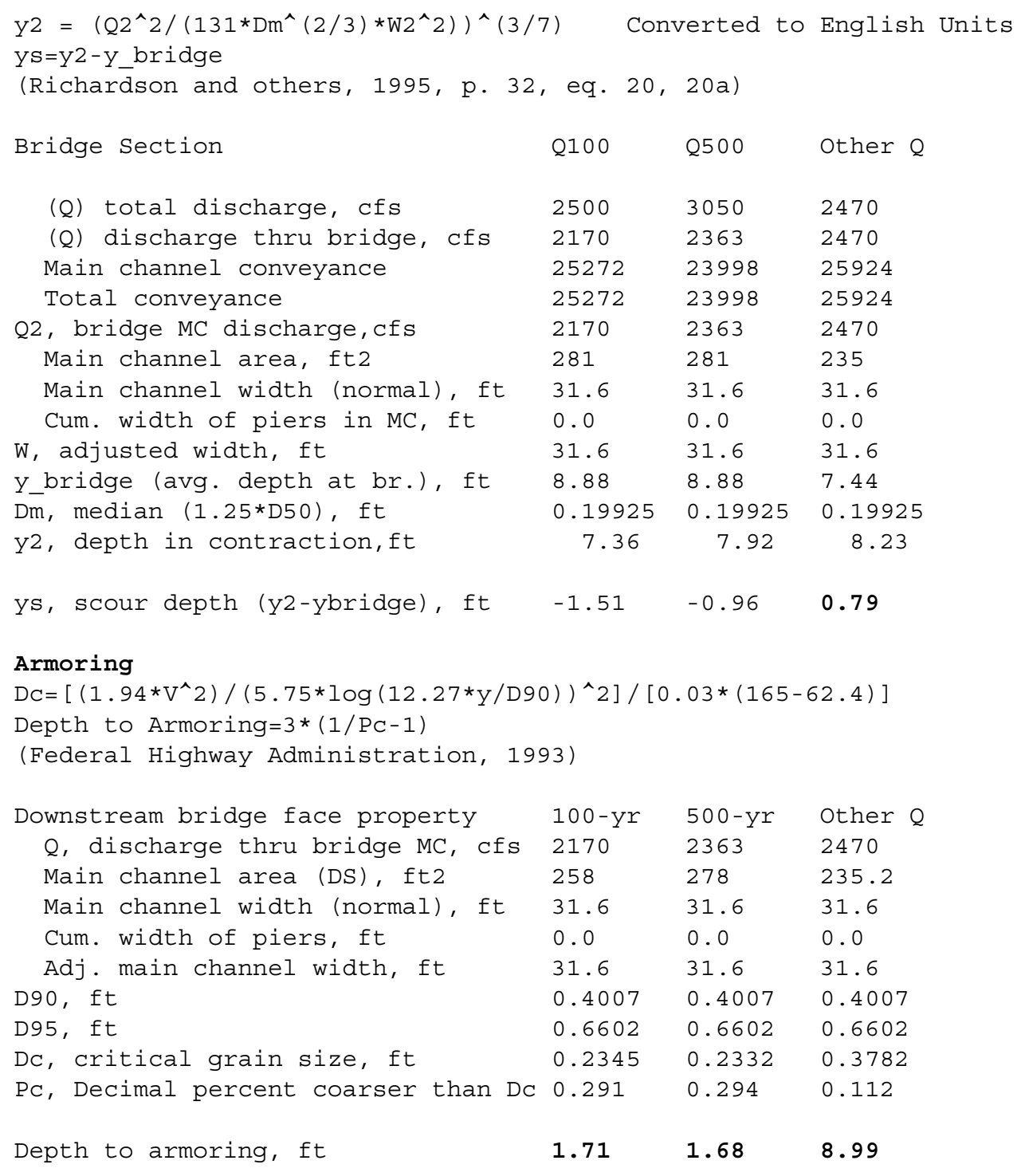




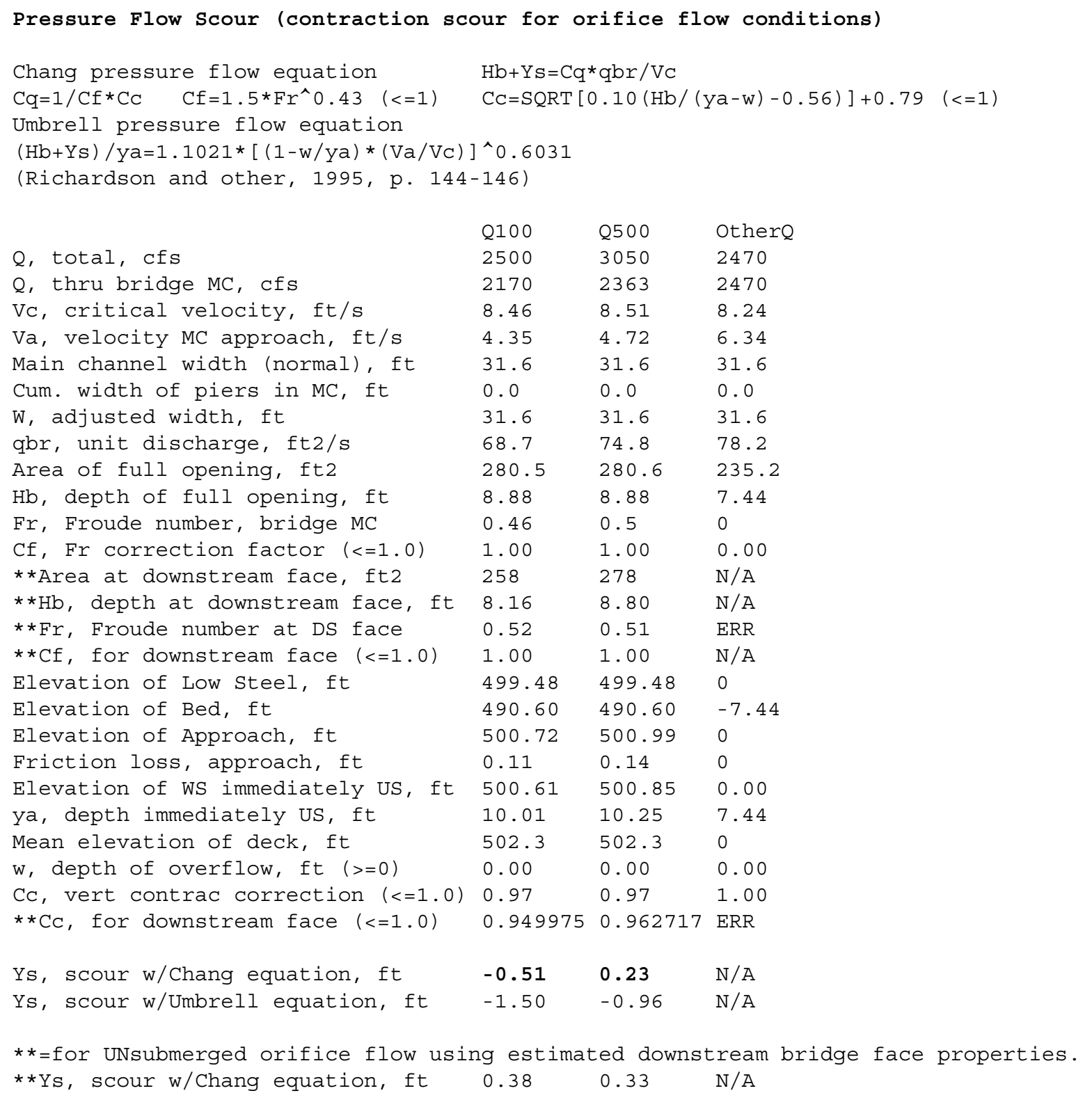




\begin{tabular}{|c|c|c|c|}
\hline \multicolumn{4}{|c|}{$\begin{array}{l}\text { In UNsubmerged orifice flow, an adjusted scour depth using the Laursen } \\
\text { equation results and the estimated downstream bridge face properties } \\
\text { can also be computed (ys=y2-ybridgeDS) }\end{array}$} \\
\hline y2, from Laursen's equation, ft & 7.36 & 7.92 & 8.23 \\
\hline WSEL at downstream face, ft & 498.77 & 499.39 & -- \\
\hline Depth at downstream face, ft & 8.16 & 8.80 & $\mathrm{~N} / \mathrm{A}$ \\
\hline Is, depth of scour (Laursen), ft & -0.80 & -0.87 & $\mathrm{~N} / \mathrm{A}$ \\
\hline
\end{tabular}

\section{Abutment Scour}

Froehlich's Abutment Scour

$\mathrm{Ys} / \mathrm{Y} 1=2.27 * \mathrm{~K} 1 * \mathrm{~K} 2 *\left(\mathrm{a}^{\prime} / \mathrm{Y} 1\right)^{\wedge} 0.43 * \mathrm{Fr} 1^{\wedge} 0.61+1$

(Richardson and others, 1995, p. 48, eq. 28)

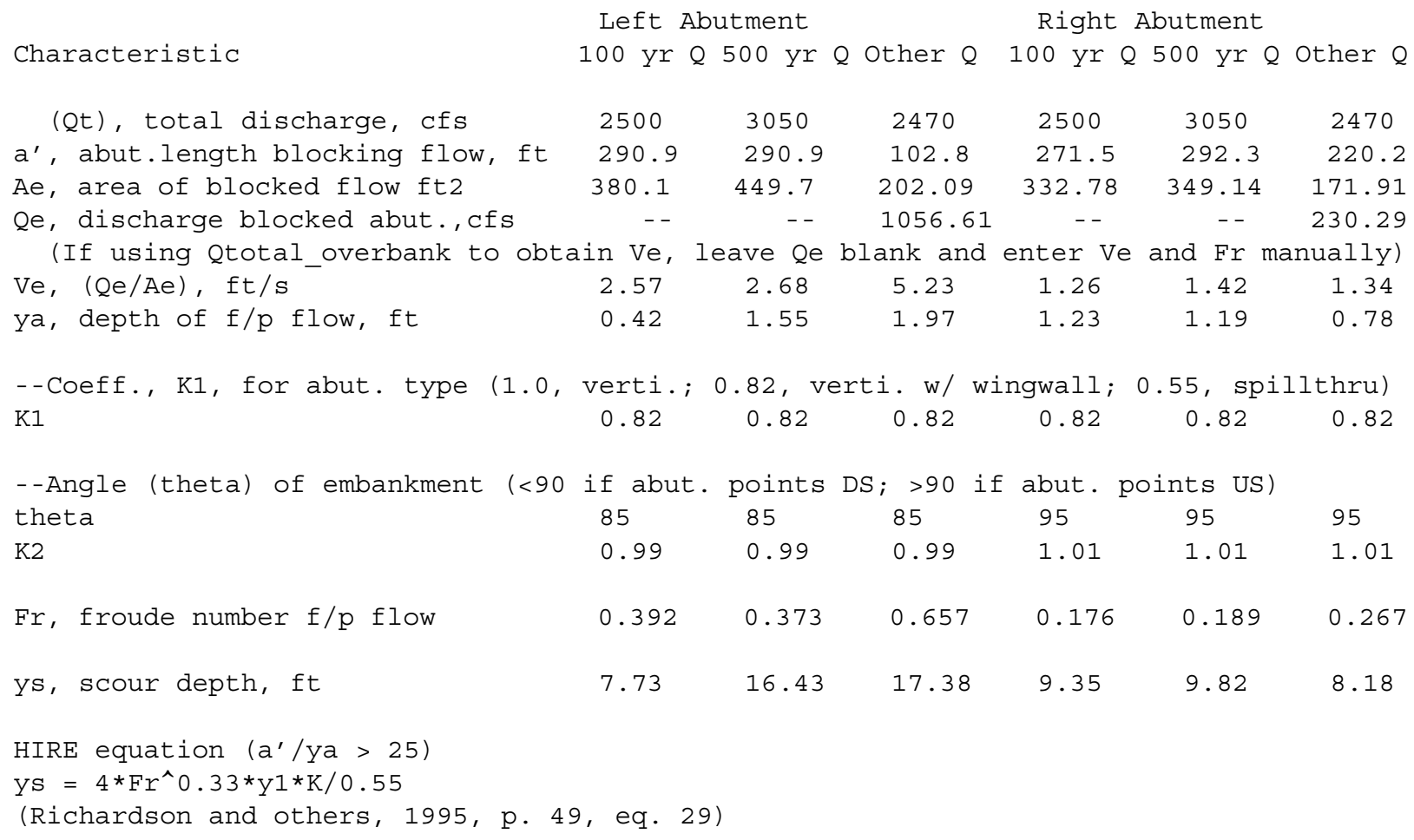




\begin{tabular}{|c|c|c|c|c|c|c|}
\hline$a^{\prime}$ (abut length blocked, ft) & 290.9 & 290.9 & 102.8 & 271.5 & 292.3 & 220.2 \\
\hline y1 (depth f/p flow, ft) & 1.31 & 1.55 & 1.97 & 1.23 & 1.19 & 0.78 \\
\hline$a^{\prime} / y^{\prime}$ & 222.63 & 188.18 & 52.29 & 221.50 & 244.71 & 282.05 \\
\hline Skew correction (p. 49, fig. 16) & 0.98 & 0.98 & 0.98 & 1.01 & 1.01 & 1.01 \\
\hline Froude no. $\mathrm{f} / \mathrm{p}$ flow & 0.39 & 0.37 & 0.66 & 0.18 & 0.19 & 0.27 \\
\hline $\begin{array}{c}\text { Ys w/ corr. factor } \mathrm{K} 1 / 0.55: \\
\text { vertical }\end{array}$ & 6.86 & 7.98 & 12.24 & 5.08 & 5.07 & 3.71 \\
\hline vertical w/ $\mathrm{ww}^{\prime} \mathrm{s}$ & 5.62 & 6.54 & 10.03 & 4.17 & 4.16 & 3.05 \\
\hline spill-through & 3.77 & 4.39 & 6.73 & 2.79 & 2.79 & 2.04 \\
\hline Abutment riprap sizing & & & & & & \\
\hline $\begin{array}{l}\text { Isbash Relationship } \\
\text { D50 }=\mathrm{Y}^{\star} \mathrm{K}^{*} \mathrm{Fr} \mathrm{r}^{\wedge} /(\mathrm{Ss}-1) \text { and } \mathrm{D} 50=\mathrm{Y}^{*} \mathrm{~K} * \\
\text { (Richardson and others, 1995, p11 }\end{array}$ & $\begin{array}{l}\left.r^{\wedge} 2\right)^{\wedge} 0.1 \\
\text {, eq. } 81\end{array}$ & $\begin{array}{l}(\mathrm{SS}-1) \\
82)\end{array}$ & & & & \\
\hline Characteristic & Q100 & Q500 & Other Q & Q100 & Q500 & Other Q \\
\hline Fr, Froude Number & 0.52 & 0.51 & 0.68 & 0.52 & 0.51 & 0.68 \\
\hline y, depth of flow in bridge, ft & 8.16 & 8.80 & 7.44 & 8.16 & 8.80 & 7.44 \\
\hline Median stone Diameter for riprap & $=$ left & butment & & right & abutment, & ft \\
\hline Fr<=0.8 (vertical abut.) & 1.36 & 1.41 & 2.13 & 1.36 & 1.41 & 2.13 \\
\hline Fr>0.8 (vertical abut.) & $\mathrm{ERR}$ & ERR & $\mathrm{ERR}$ & $\mathrm{ERR}$ & ERR & $\mathrm{ERR}$ \\
\hline
\end{tabular}

